Article

\title{
The Application of the Hybrid GIS Spatial Multi-Criteria Decision Analysis Best-Worst Methodology for Landslide Susceptibility Mapping
}

\author{
Ljubomir Gigović $^{1}{ }^{1}$, Siniša Drobnjak ${ }^{2}$ (i) and Dragan Pamučar ${ }^{3, *(\mathbb{C}}$ \\ Department of Geography, University of Defence, 11000 Belgrade, Serbia; gigoviclj@gmail.com \\ Military Geographical Institute, 11000 Belgrade, Serbia; sdrobnjak81@gmail.com \\ 3 Department of Logistics, University of Defence, 11000 Belgrade, Serbia \\ * Correspondence: dpamucar@gmail.com; Tel.: +381-64-237-7908
}

Received: 14 December 2018; Accepted: 11 February 2019; Published: 12 February 2019

check for updates

\begin{abstract}
The main goal of this article is to produce a landslide susceptibility map by using the hybrid Geographical Information System (GIS) spatial multi-criteria decision analysis best-worst methodology (MCDA-BWM) in the western part of the Republic of Serbia. Initially, a landslide inventory map was prepared using the National Landslide Database, aerial photographs, and also by carrying out field surveys. A total of 1082 landslide locations were detected. This methodology considers the fifteen conditioning factors that are relevant to landslide susceptibility mapping: the elevation, slope, aspect, distance to the road network, distance to the river, distance to faults, lithology, the Normalized Difference Vegetation Index (NDVI), the Topographic Wetness Index (TWI), the Stream Power Index (SPI), the Sediment Transport Index (STI), annual rainfall, the distance to urban areas, and the land use/cover. The expert evaluation takes into account the nature and severity of the observed criteria, and it was tested by using two scenarios: the different aggregation methods of the BWM. The prediction performances of the generated maps were checked by the receiver operating characteristics (ROCs). The validation results confirmed that the areas under the ROC curve for the weighted linear combination (WLC) and the ordered weighted averaging (OWA) aggregation methods of the MCDA-BWM have a very high accuracy. The results of the landslide susceptibility assessment obtained by applying the proposed best-worst method were the first step in the development of landslide risk management and they are expected to be used by local governments for effective management planning purposes.
\end{abstract}

Keywords: GIS modeling; landslide susceptibility assessment; best-worst multi-criteria decisionmaking; expert knowledge

\section{Introduction}

Landslides are the most dangerous natural geologic processes that cause different types of damage and also affect people, industries, and the environment, especially in times of dramatic climate change effects on the one hand, and urban sprawl and land consumption on the other. Throughout the world, hundreds of thousands of houses and buildings have been destroyed and many people have been injured by and died due to landslides. Because of this, landslide susceptibility mapping provides us with one of the crucial pieces of information in spatial planning for landslide susceptibility areas and is very important for the economic, cultural, environmental, and social sustainability of human beings. As a consequence, the study of landslide susceptibility mapping is rapidly becoming the focus of major scientific research, engineering study, and practices throughout the world [1]. Many researchers have pursued work with the intention of predicting and preventing landslide hazards by using a 
wide variety of methods. A landslide susceptibility map represents the areas with the potential for landslides in the future by combining some of the critical factors that contributed to the occurrence of past landslides [2].

The spatial prediction of landslides using the production of landslide susceptibility maps is the first important step for landslide disaster and hazard management. The spatial probability of a landslide vulnerability can be expressed as the probability of the spatial occurrence of slope failures with a set of geo-environmental conditions. However, due to the complex nature of landslides, producing a reliable spatial prediction of landslide susceptibility is not easy [3].

Landslides are caused by various factors, such as topography, geology, soil characteristics, forest conditions, and climate variables [4]. By applying various Geographical Information System (GIS)-based techniques and spatial data, different methods can be used to ultimately determine the level of landslide hazard and susceptibility [5]. A GIS model can be used to combine a set of maps or factors using a function in order to produce the final map [6]. The function can take numerous structures, including discriminate analysis, conditional analysis, linear regression, and multiple regression, etc. [7,8]. There are several different approaches to the production of the landslide susceptibility and hazard map of a region (Table 1).

The main difference between the present study and the approaches described in the aforementioned references in Table 1 is that a GIS-based best-worst multi-criteria decision analysis (GIS-MCDA-BW) by different parameters was applied, its results being compared for landslide susceptibility in the western part of the Republic of Serbia. Specifically, we used a novel BW method to determine the connections in the network structure based on the criteria and accepted imprecisions during collective decision-making. Therefore, the quality of the existing data during collective decision-making and the experts' perceptions expressed through an aggregation matrix can be retained. The final susceptibility map was obtained by using the weighted linear combination (WLC) and the ordered weighted averaging (OWA) aggregation methods.

Table 1. Summarized several landslide susceptibility and hazard map approaches.

\begin{tabular}{|c|c|c|}
\hline Approaches & Methods & Short Description (References) \\
\hline \multirow{3}{*}{$\begin{array}{l}\text { Geotechnical } \\
\text { approaches }\end{array}$} & Deterministic methods & $\begin{array}{l}\text { Deterministic methods are mainly based on the geotechnical and groundwater } \\
\text { properties of the rock and soil of unstable areas. In this case, specific } \\
\text { mathematical models are used to find the factor of the safety of unstable slopes, } \\
\text { and slope stability models are used to determine landslide hazard [9]. }\end{array}$ \\
\hline & Safety factor method & $\begin{array}{l}\text { The safety factor method uses slope-displacement-simulated models, which are } \\
\text { based on identifying the most dangerous sliding surface in order to calculate the } \\
\text { factor for analyzing the slope stability [10-12]. }\end{array}$ \\
\hline & Probabilistic methods & $\begin{array}{l}\text { The probabilistic approach considers whether future environmental conditions } \\
\text { will meet the requirements for a landslide identified in previous landslides. Thus, } \\
\text { the probabilistic analysis considers the statistical relationships between the } \\
\text { historical landslide locations and the landslide conditioning factors [13-16]. }\end{array}$ \\
\hline \multirow{4}{*}{$\begin{array}{l}\text { Heuristic or } \\
\text { index-based } \\
\text { approaches }\end{array}$} & $\begin{array}{l}\text { Analytic hierarchy } \\
\text { process }(\mathrm{AHP})\end{array}$ & $\begin{array}{l}\text { The AHP mainly depends on the knowledge of experts, who assign a priority to } \\
\text { each parameter and establish sub-criteria from pairwise comparisons. The } \\
\text { process is based on the three principles: decomposition, comparative judgment, } \\
\text { and the synthesis of data [16-18]. }\end{array}$ \\
\hline & $\begin{array}{l}\text { Weighted linear } \\
\text { combination (WLC) } \\
\text { method }\end{array}$ & $\begin{array}{l}\text { The WLC method starts with a comparison of the data-layers corresponding to } \\
\text { the landslide controlling parameters and the landslide inventory map, and } \\
\text { involves the computation of the landslide density so as to assign primary-level } \\
\text { weights for each class of a particular parameter. The final steps of this method } \\
\text { are a combination of all the weighted layers into a single map, and the } \\
\text { classification of the scores of this map into landslide susceptibility }[19,20] \text {. }\end{array}$ \\
\hline & $\begin{array}{l}\text { Spatial multicriteria } \\
\text { decision analysis } \\
\text { (MCDA) }\end{array}$ & $\begin{array}{l}\text { The MCDA can be defined as a decision aid and a mathematical tool allowing } \\
\text { the comparison of different alternatives or scenarios according to many, often } \\
\text { conflicting, criteria in order to guide the decision-maker towards a judicious } \\
\text { choice }[16,21] \text {. }\end{array}$ \\
\hline & $\begin{array}{l}\text { Index of entropy (IoE) } \\
\text { method }\end{array}$ & $\begin{array}{l}\text { The entropy method has been widely used to determine the weighted index of } \\
\text { natural hazards and carry out integrated environmental assessments of natural } \\
\text { processes. The entropy of a landslide represents the factors influencing its } \\
\text { development, and its value can be used to calculate the objective weights of the } \\
\text { index system [22,23]. }\end{array}$ \\
\hline
\end{tabular}


Table 1. Cont.

\begin{tabular}{|c|c|c|}
\hline Approaches & Methods & Short Description (References) \\
\hline \multirow{4}{*}{$\begin{array}{l}\text { Statistical } \\
\text { methods } \\
\text { approaches }\end{array}$} & Bivariate analysis & $\begin{array}{l}\text { In bivariate analysis, each individual factor is combined with a landslide } \\
\text { distribution map, and the weight values based on the landslide densities are } \\
\text { calculated for each parameter class }[9,24-26] \text {. }\end{array}$ \\
\hline & Multivariate analysis & $\begin{array}{l}\text { In multivariate analysis, many causative factors are sampled, and for each of the } \\
\text { sampling units, the presence or absence of landslides is also determined. This } \\
\text { analysis allows the estimation of the relative weights of each contributing factor } \\
\text { by means of statistical procedures. There is a trend towards using multivariate } \\
\text { statistical analysis, such as discriminant analysis, factor analysis, logistic } \\
\text { regression analysis, and conditional analysis [2,27]. }\end{array}$ \\
\hline & $\begin{array}{l}\text { Statistical index (SI) } \\
\text { method }\end{array}$ & $\begin{array}{l}\text { The SI method, bivariate statistical analysis, is considered as the simplest and } \\
\text { quantitatively suitable method in landslide susceptibility mapping. In this } \\
\text { method, the weighting value for each categorical unit is defined as the natural } \\
\text { logarithm of the landslide density in the class divided by the landslide density in } \\
\text { the whole studied area }[28,29] \text {. }\end{array}$ \\
\hline & $\begin{array}{l}\text { Weights of evidence } \\
\text { (WoE) method }\end{array}$ & $\begin{array}{l}\text { Weights of evidence (WoE), based on Bayesian Bayes' theorem and the } \\
\text { assessment of the relationship between the spatial distribution of the areas } \\
\text { affected by landslides and the spatial distribution of the conditioning factors } \\
\text { causing landslides, is one of bivariate models [30-32]. }\end{array}$ \\
\hline \multirow{9}{*}{$\begin{array}{l}\text { Soft computing } \\
\text { and data mining } \\
\text { approaches }\end{array}$} & Fuzzy logic method & $\begin{array}{l}\text { The idea of using a fuzzy approach in landslide susceptibility mapping is to } \\
\text { consider the pixels on any causal factor layer as susceptible to landslides. Pixel } \\
\text { values can be numeric and range from } 0 \text { (i.e., "not susceptible") to } 1 \text { (i.e., } \\
\text { "susceptible") [33-35]. }\end{array}$ \\
\hline & $\begin{array}{l}\text { Artificial neural network } \\
\qquad(\text { ANN) }\end{array}$ & $\begin{array}{l}\text { The ANN is the statistical learning algorithm that describes the neuronal } \\
\text { signaling system [36-40]. }\end{array}$ \\
\hline & Neuro-fuzzy method & $\begin{array}{l}\text { The neuro-fuzzy method is the neural network that is functionally equivalent to } \\
\text { the fuzzy inference model. It can be trained to develop "if-then" fuzzy rules and } \\
\text { determine the membership functions for the input and the output variables of } \\
\text { the system. One of the neuro-fuzzy inference systems is the adaptive } \\
\text { neuro-fuzzy inference system (ANFIS) [41-43]. }\end{array}$ \\
\hline & $\begin{array}{l}\text { Support vector machines } \\
\text { method (SVM) }\end{array}$ & $\begin{array}{l}\text { The SVM method is a training algorithm based on the non-linear transformations } \\
\text { that use the classification based on the principle of structural risk minimization, } \\
\text { which has performed well in the test phase. The SVM model performs this } \\
\text { process according to the three main concepts: the margin, the support vector, and } \\
\text { the kernel }[39,44,45] \text {. }\end{array}$ \\
\hline & $\begin{array}{l}\text { Evidential belief function } \\
\text { method }\end{array}$ & $\begin{array}{l}\text { The EBFs are the compound of Bel (the degree of belief), Dis (the degree of } \\
\text { disbelief), Unc (the degree of uncertainty), and Pls (the degree of plausibility). } \\
\text { The main parts of the theory are represented by Bel = a lower probability and Pls } \\
=\text { an upper probability }[45,46] \text {. }\end{array}$ \\
\hline & Decision tree method & $\begin{array}{l}\text { The decision tree (DT) approach is a recently developed probabilistic approach } \\
\text { based on the multivariate methods that are mainly used for classification } \\
\text { schemes [47-49]. }\end{array}$ \\
\hline & $\begin{array}{l}\text { Naïve Bayes (NB) } \\
\text { method }\end{array}$ & $\begin{array}{l}\text { The NB classifier is a classification system based on Bayes' theorem assuming } \\
\text { that all attributes are fully independent given the output class, called the } \\
\text { conditional independence assumption }[45,50] \text {. }\end{array}$ \\
\hline & Frequency ratio method & $\begin{array}{l}\text { The frequency ratio is the ratio of the area where landslides have occurred and } \\
\text { the total study area, also being the ratio of the probabilities of the landslide } \\
\text { occurrence to non-occurrence for a given attribute }[26,51,52] \text {. }\end{array}$ \\
\hline & Random forest method & $\begin{array}{l}\text { Random forest is an ensemble-learning technique. It generates many } \\
\text { classification trees aggregated so as to compute a classification. The Random } \\
\text { forest algorithm has resistance to outliers in predictors and automatically } \\
\text { handles the missing values. The random forest technique estimates the } \\
\text { importance of a predictive variable [53]. }\end{array}$ \\
\hline
\end{tabular}

\section{Study Area and Data}

\subsection{Study Area}

The study area covers approximately $5067 \mathrm{~km}^{2}$ between the latitudes $43^{\circ} 46^{\prime} 26^{\prime \prime}$ to $44^{\circ} 56^{\prime} 10^{\prime \prime} \mathrm{N}$, and the longitudes $19^{\circ} 06^{\prime} 46^{\prime \prime}$ to $20^{\circ} 14^{\prime} 56^{\prime \prime} \mathrm{E}$, and is located in the western part of the Republic of Serbia (Figure 1). The study area consists of Serbian Mačva and Kolubara Districts, and the Tara National Park. The elevation of the study area ranges from 0 to $1586 \mathrm{~m}$ above mean sea level (MSL). 


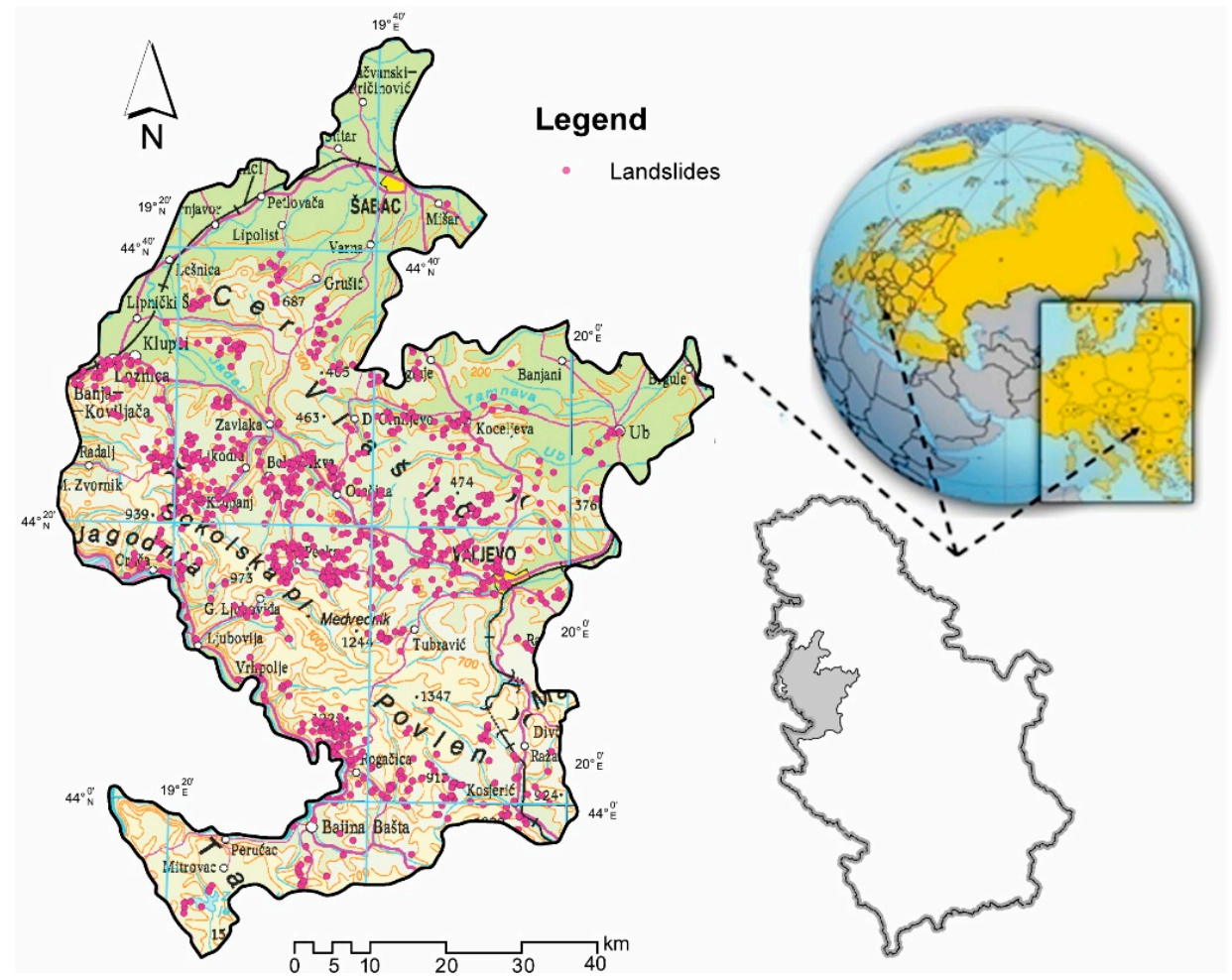

Figure 1. The location of the study area (Mačva and Kolubara Districts, and the Tara National Park).

The slope angles of the area range from $0^{\circ}$ to as much as $89^{\circ}$. The total annual rainfall in the different parts of the study region ranges from 623 to $1055 \mathrm{~mm}$. Based on the records obtained from the Serbian Meteorological Service, the maximum rainfall occurs between March and June. The study area is heterogeneous in terms of the terrain complexity, which consists of plain and mountainous areas.

\subsection{Data}

The detection of the accurate location of a landslide and the creation of the historical database record is a very important primary process for performing landslide susceptibility analysis. However, the detection of the landslide location is often a challenging and time-consuming process [54]. The National Landslide Database was created by the Ministry of Mining and Energy of the Republic of Serbia within the BEWARE (Beyond Landslide Awareness) project, which represents a standardized post-event landslide database closely involving the local community of 27 municipalities, preparing them to cope with landslide hazard events in the future. The BEWARE (GIS) web portal is a platform for reporting interactive landslide events and unifying landslide data records.

The landslide inventory map is an important step in landslide susceptibility mapping. Therefore, field survey, high-resolution images, and aerial photo interpretation methods were applied in this study to generate the landslide inventory map. The landslide conditioning factor is yet another key topic, which has been researched many scientists. Hence, the elevation, the slope, the aspect, the topographic wetness index (TWI), the sediment transport index (STI), the stream power index (SPI), the normalized difference vegetation index (NDVI), the distance to the river, the distance to roads, the distance to the urban areas, rainfall, the land cover/use, lithology, and the soil type were used in this study in order to analyze landslide susceptibility. Detailed information regarding the landslide conditioning factors' sources are given in Table 2. 
Table 2. The data used in the susceptibility assessment, the data sources, and the associated factor classes for the landslide susceptibility mapping in the study area.

\begin{tabular}{|c|c|c|c|c|c|}
\hline Sub-Classification & Data Layers & Source of Data & Data Type & Derived Map & Scale or Resolution \\
\hline \multirow[t]{7}{*}{$\begin{array}{l}\text { Landslide } \\
\text { Inventory } \\
\text { Database }\end{array}$} & Historic Landslide & $\begin{array}{l}\text { BEWARE project (BEyond landslide aWAREness), Ministry of } \\
\text { Mining and Energy of the Republic Serbia } \\
\text { (http:/ / geoliss.mre.gov.rs/beware/webgis/OpenData.php) }\end{array}$ & Point & - & - \\
\hline & Elevation & $\begin{array}{l}\text { Digital Elevation Model (DEM) generated by Topographic } \\
\text { database layer, contour lines with 10-m intervals }\end{array}$ & Grid & Elevation & $20 \mathrm{~m}$ \\
\hline & Slope & $\begin{array}{l}\text { DEM generated by Topographic database layer, contour lines } \\
\text { with } 10-\mathrm{m} \text { intervals }\end{array}$ & Grid & $\begin{array}{l}\text { Slope gradient } \\
\text { (in degrees) }\end{array}$ & $20 \mathrm{~m}$ \\
\hline & Aspect & $\begin{array}{l}\text { DEM generated by Topographic database layer, contour lines } \\
\text { with } 10 \text {-m intervals }\end{array}$ & Grid & Aspect & $20 \mathrm{~m}$ \\
\hline & $\begin{array}{l}\text { Topographic wetness index } \\
\text { (TWI) }\end{array}$ & $\begin{array}{l}\text { DEM generated by Topographic database layer, contour lines } \\
\text { with } 10-\mathrm{m} \text { intervals }\end{array}$ & Grid & $\begin{array}{c}\text { Topographic } \\
\text { wetness index }\end{array}$ & $20 \mathrm{~m}$ \\
\hline & Stream power index (SPI) & $\begin{array}{l}\text { DEM generated by Topographic database layer, contour lines } \\
\text { with } 10-\mathrm{m} \text { intervals }\end{array}$ & Grid & $\begin{array}{l}\text { Stream power } \\
\text { index }\end{array}$ & $20 \mathrm{~m}$ \\
\hline & $\begin{array}{l}\text { Sediment transport index } \\
\text { (STI) }\end{array}$ & $\begin{array}{l}\text { DEM generated by Topographic database layer, contour lines } \\
\text { with } 10-m \text { intervals }\end{array}$ & Grid & $\begin{array}{l}\text { Sediment } \\
\text { transport index }\end{array}$ & $20 \mathrm{~m}$ \\
\hline Soil & Soil & $\begin{array}{c}\text { National soil data } \\
\text { http:/ /h05-prod-vm15.jrc.it/content/soil-map-serbia- } \\
\text { pedoloska-karta-jugoslavije }\end{array}$ & Polygon & Soil & $1: 100,000$ \\
\hline Geology Map & Litho types & $\begin{array}{l}\text { Ministry of Energy, Development and Environmental } \\
\text { Protection of the Republic of Serbia } \\
\text { http://geoliss.mre.gov.rs/?lang=en }\end{array}$ & $\begin{array}{l}\text { Arc/Info } \\
\text { coverage }\end{array}$ & Lithology & $1: 100,000$ \\
\hline Geology Map & Distance to faults & $\begin{array}{l}\text { Ministry of Energy, Development and Environmental } \\
\text { Protection of the Republic of Serbia }\end{array}$ & Line & Distance to fault & \\
\hline Land Use Type & Land use & Landsat 8 Operational Land Imager (OLI) images & Grid & Land use & $30 \mathrm{~m}$ \\
\hline $\begin{array}{l}\text { Normalized Difference } \\
\text { Vegetation Index (NDVI) }\end{array}$ & NDVI & Landsat 8 OLIimages & Grid & NDVI & $30 \mathrm{~m}$ \\
\hline Rainfall & Rainfall & $\begin{array}{l}\text { Republic Hydrometeorological Service of Serbia } \\
\text { (http://www.hidmet.gov.rs/index_eng.php) }\end{array}$ & Grid & $\begin{array}{l}\text { Precipitation } \\
\text { map (mm) }\end{array}$ & $1: 50,000$ \\
\hline River & River network & Military Geographical Institute (MGI) digital topographic map & Line & Distance to river & $1: 25,000$ \\
\hline Roads & Road network & MGI digital topographic map & Line & Distance to road & $1: 25,000$ \\
\hline Urban Areas & Urban areas & MGI digital topographic map & Polygon & $\begin{array}{l}\text { Distance to } \\
\text { urban areas }\end{array}$ & $1: 25,000$ \\
\hline
\end{tabular}




\section{Methodology}

\subsection{Methodological Background}

The methodological hierarchy in this paper is based on the GIS multi-criteria decision analysis (GIS-MCDA) structure. This approach uses the capabilities of GIS in the management of geospatial data and the flexibility of the MCDA to combine factual pieces of information (e.g., land use, slope, aspect, TWI, etc.) with value-based information (e.g., expert opinion, standards, surveys, etc.) [55]. The main advantage of integrating GIS and the MCDA can be seen in their specific capabilities supplementing each other [56]. From a methodological point of view, the defined landslide susceptibility areas in the western part of the Republic of Serbia include the following main steps (Figure 2).

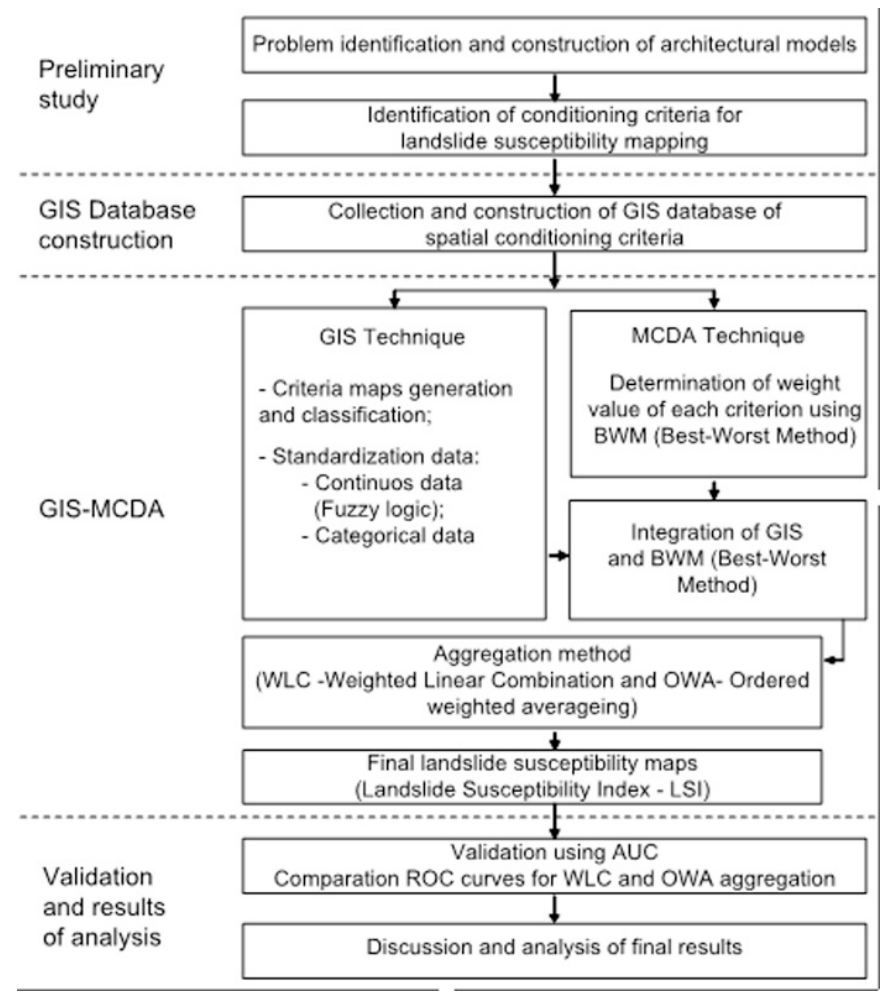

Figure 2. The flowchart of the applied methodology.

The primary advantages of the BW method for the landslide susceptibility mapping [57-59] suggested by the authors are as follows: (1) compared with the analytic hierarchy process (AHP) method, which is most commonly used in the literature to determine weight coefficients [60], it requires significantly fewer pairwise comparisons (the AHP method requires $n(n-1) / 2$ comparisons, the BW $2 n-3$ comparisons); (2) the values of the weight coefficients obtained by the BW method are more reliable because comparison in the BW method is carried out with a higher consistency ratio compared with the AHP method; (3) while for the majority of MCDM models (e.g., the AHP) the consistency ratio is a test of whether the criteria comparison is consistent or not, in the BW method the consistency ratio is used to determine the level of confidence since the BW outputs are always consistent; (4) the BW model only uses integers for the criteria pairwise comparison, as opposed to the other MCDM methods (e.g., the AHP), which also require the use of fractional numbers [61].

Since the method is of a very recent date, the literature has, so far, only contained the traditional (crisp) BW method [57-59,62] and the modification of the BW method performed by using fuzzy numbers [63]. The following section presents the algorithm for the BW method that includes the following steps: 
Step 1. Determining a set of evaluation criteria. This starts from the assumption that the process of decision-making involves $m$ experts. In this step, the experts consider a set of evaluation criteria and select the final set of the criteria $C=\left\{c_{1}, c_{2}, \ldots c_{n}\right\}$, where $n$ represents the total number of the criteria.

Step 2. Determining the most significant (the best) and the least significant (the worst) criteria. The experts decide on the best and the worst criteria from the set of criteria $C=\left\{c_{1}, c_{2}, \ldots c_{n}\right\}$. If the experts decide on two or more criteria as the best, or the worst, the best and the worst criteria are arbitrarily selected.

Step 3. Determining the preferences of the most significant (the most influential) criteria $(B)$ from within the set $C$ over the remaining criteria from the defined set. Under the assumption that there are $m$ experts and $n$ criteria under consideration, each expert should determine the degree of the influence of the best criterion $B$ on the criteria $j(j=1,2, \ldots, n)$. This is how a comparison between the best criterion and the other criteria is obtained. The preference of the criterion $B$ compared to the $j$-th criterion defined by the $e$-th expert is denoted by $a_{B j}^{e}(j=1,2, \ldots, n ; 1 \leq e \leq m)$. The value of each pair $a_{B j}^{e}$ takes a value between 1 and 9 [58].

As a result, the Best-to-Others (BO) vector is obtained:

$$
A_{B}^{e}=\left(a_{B 1}^{e}, a_{B 2}^{e}, \ldots, a_{B n}^{e}\right) ; 1 \leq e \leq m
$$

where $a_{B j}^{e}$ represents the influence (preference) of the best criterion $B$ on (over) criterion $j$, whereby $a_{B B}^{e}=1$. This is how the fuzzy $\mathrm{BO}$ matrices $A_{B}^{1}, A_{B}^{2}, \ldots, A_{B}^{m}$ are obtained for each expert.

Step 4. Determining the preferences of the criteria from the set $C$ over the worst criterion $(W)$ from the defined set. Each expert should determine the degree of the influence of the criterion $j$ $(j=1,2, \ldots, n)$ in relation to the criterion $W$. The preference of the criterion $j$ in relation to the criterion $W$ defined by the $e$-th expert is denoted as $a_{j W}^{e}(j=1,2, \ldots, n ; 1 \leq e \leq m)$. The value of each pair $a_{j W}^{e}$ takes a value between 1 and 9 . As a result, the Others-to-Worst $(\mathrm{OW})$ vector is obtained:

$$
A_{W}^{e}=\left(a_{1 W}^{e}, a_{2 W}^{e}, \ldots, a_{n W}^{e}\right) ; 1 \leq e \leq m
$$

where $a_{j W}^{e}$ represents the influence (preference) of the criterion $j$ in relation to the criterion $W$, whereby $a_{W W}^{e}=1$. This is how the fuzzy OW matrices $A_{W}^{1}, A_{W}^{2}, \ldots, A_{W}^{m}$ are obtained for each expert.

Step 5. Determining the BO matrix for the experts' average answers. Based on the $\mathrm{BO}$ matrices of the experts' answers $A_{B}^{e}=\left[a_{B j}^{e}\right]_{1 \times n^{\prime}}$, the matrices of the aggregated sequences of experts are formed as follows:

$$
A_{B}^{* e}=\left[a_{B 1}^{1}, a_{B 1}^{2}, \ldots, a_{B 1}^{m} ; a_{B 2}^{1} ; a_{B 2}^{2} ; \ldots ; a_{B 2}^{m}, \ldots, a_{B n}^{1} ; a_{B n}^{2}, \ldots, a_{B n}^{m}\right]_{1 \times n}
$$

where $a_{B j}^{e}=\left\{a_{B j}^{1}, a_{B j}^{2}, \ldots, a_{B n}^{m}\right\}$ represent the sequences of $a_{B j}^{e}$, by means of which the relative significance of the criterion $B$ is described in relation to the criterion $j$.

Finally, by applying Equation (3), the average BO matrix is obtained:

$$
\bar{a}_{B j}=\frac{1}{m} \sum_{e=1}^{m} a_{B j}^{e}
$$

where $e$ represents the $e$-th expert $(e=1,2, \ldots, m), a_{B j}^{e}$ represents the sequence that describes the relative significance of the criterion $B$ in relation to the criterion $j$. Thus, the averaged $\mathrm{BO}$ matrix of the average responses $A_{B}$ is thus obtained:

$$
A_{B}=\left[\bar{a}_{B 1}, \bar{a}_{B 2}, \ldots, \bar{a}_{B n}\right]_{1 \times n}
$$


Step 6. Determining the $\mathrm{OW}$ matrix of the experts' average responses. Based on the $\mathrm{OW}$ matrices of the experts' responses $A_{W}^{e}=\left[a_{j W}^{e}\right]_{1 \times n^{\prime}}$, as with the BO matrices, the matrices of the experts aggregated sequences are formed:

$$
A_{W}^{* e}=\left[a_{1 W}^{1}, a_{1 W}^{2}, \ldots, a_{1 W}^{m} ; a_{2 W}^{1} ; a_{2 W}^{2} ; \ldots ; a_{2 W}^{m}, \ldots, a_{n W}^{1} ; a_{n W}^{2}, \ldots, a_{n W}^{m}\right]_{1 \times n}
$$

where $a_{j W}^{e}=\left\{a_{j W}^{1}, a_{j W}^{2}, \ldots, a_{n W}^{m}\right\}$ represents the sequences of $a_{j W}^{e}$, by means of which the relative significance of the criterion $j$ is described in relation to the criterion $W$.

Finally, by applying Equation (6), the average OW matrix is obtained:

$$
\bar{a}_{j W}=\frac{1}{m} \sum_{e=1}^{m} a_{j W}^{e}
$$

where $e$ represents the $e$-th expert $(e=1,2, \ldots, m), a_{j W}^{e}$ represents the sequence describing the relative significance of the criterion $j$ in relation to the criterion $W$. Thus, the averaged OW matrix of the average responses $A_{W}$ is obtained:

$$
A_{W}=\left[a_{1 W}, a_{2 W}, \ldots, a_{n W}\right]_{1 \times n}
$$

Step 7. The calculation of the optimal values of the weight coefficients of the criteria $\left[w_{1}, w_{2}, \ldots, w_{n}\right]$ from the set $C$. The goal is to determine the optimal value of the evaluation criteria, which should satisfy the condition that the difference in the maximum absolute values (8)

$$
\left|\frac{w_{B}}{w_{j}}-a_{B j}\right| \text { and }\left|\frac{w_{j}}{w_{W}}-a_{j W}\right|
$$

for each value of $j$ is minimized. In order to meet these conditions, the solution that satisfies the maximum differences according to the absolute value $\left|\frac{w_{B}}{w_{j}}-a_{B j}\right|$ and $\left|\frac{w_{j}}{w_{W}}-a_{j W}\right|$ should be minimized for all the values of $j$. The previously defined limits will be presented in the following min-max model:

$$
\begin{aligned}
& \min _{j} \max _{j}\left\{\left|\frac{w_{B}}{w_{j}}-a_{B j}\right|,\left|\frac{w_{j}}{w_{w}}-a_{j W}\right|\right\} \\
& \text { s.t. } \\
& \left\{\begin{array}{l}
\sum_{j=1}^{n} w_{j}=1 \\
w_{j} \geq 0, \forall j=1,2, \ldots, n
\end{array}\right.
\end{aligned}
$$

where $w_{B}$ represents the weight of the best criterion, $w_{W}$ the weight of the worst criterion, and $w_{j}$ the weight of the $j$-th criterion. Model (10) is equivalent to the following model:

$$
\begin{aligned}
& \min \xi \\
& \text { s.t. } \\
& \left\{\begin{array}{l}
\left|\frac{w_{B}}{w_{j}}-a_{B j}\right| \leq \xi ; \forall j=1,2, \ldots, n \\
\frac{w_{j}}{w_{w}}-a_{j W} \mid \leq \xi ; \forall j=1,2, \ldots, n \\
\sum_{j=1}^{n} w_{j}=1 \\
w_{j} \geq 0, \forall j=1,2, \ldots, n
\end{array}\right.
\end{aligned}
$$

where $w_{j}$ represents the optimum values of the weight coefficients, $w_{B}$ and $w_{W}$ represent the weight coefficients of the best and the worst criteria, respectively, whereas $a_{j W}$ and $a_{B j}$, respectively represent the values from the average $\mathrm{OW}$ and $\mathrm{BO}$ vectors (see Equations (4) and (7)).

By solving Model (11), the optimal values of the weight coefficients of the evaluation criteria $\left[w_{1}, w_{2}, \ldots, w_{n}\right]$ and $\xi^{*}$ are obtained. 


\subsection{The Consistency Ratio of the Best-Worst Methodology (BWM)}

The consistency ratio is a very important indicator, by means of which the consistency of the pairwise comparison of the criteria in the $\mathrm{BO}$ and $\mathrm{OW}$ matrices is checked.

Definition 1. The comparison of criteria is consistent when the condition $a_{B j} \times a_{j W}=a_{B W}$ is fulfilled for all of the criteria $j$, where $a_{B j}, a_{j W}$ and $a_{B W}$, respectively, represent the preference of the best criterion over the criterion $j$, the preference of the criterion $j$ over the worst criterion, and the preference of the best criterion over the worst criterion.

However, when comparing criteria, some pairs of the criteria $j$ may not prove to be completely consistent. Therefore, the next section defines the consistency ratio $(C R)$, which provides us with information on the consistency of the comparison between the $\mathrm{BO}$ and the $\mathrm{OW}$ vectors. In order to show how the $C R$ is determined, we start from the calculation of the minimum consistency when comparing criteria, which is explained in the following section.

As previously indicated, the pairwise comparison of the criteria is carried out based on the predefined scale in which the highest value is 9 , or any other maximum from the scale defined by the decision-maker. The consistency of the comparison decreases when $a_{B j} \times a_{j W}$ is less or greater than $a_{B W}$, i.e., when $a_{B j} \times a_{j W} \neq a_{B W}$. It is clear that the greatest inequality occurs when $a_{B j}$ and $a_{j W}$ have the maximum values equaling $a_{B W}$, which continues to affect the value of $\xi$. Based on these relationships, the following conclusion can be drawn:

$$
\left[w_{B} / w_{j}\right] \times\left[w_{j} / w_{W}\right]=w_{B} / w_{W}
$$

As the largest inequality occurs when $a_{B j}$ and $a_{j W}$ have their maximum values, the value $\xi$ needs to be subtracted from $a_{B j}$ and $a_{j W}$, and $a_{B W}$ needs to be added. Thus, Equation (13) is obtained:

$$
\left[a_{B j}-\xi\right] \times\left[a_{j W}-\xi\right]=\left[a_{B W}+\xi\right]
$$

Given the fact that the minimum consistency $a_{B j}=a_{j W}=a_{B W}$ applies, Equation (14) is presented as follows:

$$
\left(a_{B W}-\xi\right) \times\left(a_{B W}-\xi\right)=a_{B W}+\xi \Rightarrow \xi^{2}-\left(1-2 a_{B W}\right) \xi+\left(a_{B W}^{2}-a_{B W}\right)=0
$$

By solving Equation (14) for the different values of $a_{B W}$, the maximum possible values of $\xi$ can be determined, which is the $C I$ for the BWM. Since the values of $a_{B W}$ are obtained on the basis of the experts' aggregated decisions, and given the fact that these change the interval, the values of $\xi$ are impossible to predefine. The values of $\xi$ depend on uncertainties in decisions since such uncertainties change the average value. As explained in the algorithm for the BWM average values of $a_{B j}, a_{j W}$ and $a_{B W}$ change depending on uncertainties in evaluating the criteria.

Based on $C I$, the consistency ratio $(C R)$ is obtained:

$$
C R=\frac{\xi^{*}}{C I}
$$

The $C R$ takes values from interval $[0,1]$, where values closer to zero show a high consistency, whereas the values of the $C R$ closer to one show a low consistency.

\section{Results}

This section is divided into the subsections. It provides a concise and precise description of the aim of this study. It is aimed at proposing a reliable GIS-MCDA BW methodology for the landslide susceptibility mapping, which could serve as a useful tool for preventing and reducing the landslide hazard for spatial planners to create spatial policies and systems for landslide management. 
The various thematic data layers representing the landslide conditioning factors, such as the slope, the aspect, the elevation, lithology, the land use/cover, the distance to faults, the distance to rivers, the distance to roads, the topographic wetness index (TWI), the stream power index (SPI), the sediment transport index (STI), rainfall, the distance to urban areas, the soil type, and the normalized difference vegetation index (NDVI), were prepared. These factors fall under the three categories of the conditioning factors that make the area susceptible to movement without actually initiating a landslide; thus, these factors are considered to be responsible for the occurrence of landslides in the regions for which pertinent data can be collected from the available resources and from the field. The triggering factor, such as rainfall, sets the movement off by shifting the slope from a marginally stable to an actively unstable area [1]. Furthermore, the attributes of the ground in terms of landslide susceptibility were considered in the present study.

\subsection{Landslide Inventory Map}

The mapping of the actual landslides in the study area is essential for describing the relationship between the landslide distribution and the conditioning factors. In order to produce a detailed and reliable landslide inventory map, extensive field surveys and observations were performed in the study area. A total of 1082 landslides were identified and mapped in the study area by evaluating the aerial photos supported by the field survey. Also, we used the National Landslide Database of the Republic of Serbia within the BEWARE project, which represents a standardized post-event landslide database. The landslide standard spatial database contains data such as the exact location of the landslide, the width, length, depth, and volume of the landslide, the average slope data of the terrain on which the landslide is located, the general information on the landslide process, the type of the occurrence, the trend of the movement, the type of the triggered material, water content, the movement speed, the activity, the mode of the movement, as well as the terrain, vulnerability, and the landslide photos.

\subsection{Conditioning Factors}

The landslide hazard evaluation criteria selection is an important step in the analysis. It is essential to identify the landslide conditioning factors in order to create a reliable landslide susceptibility map. Based on the experts' opinions and longer observations from the field, this study adopted the fifteen criteria that are an important cause of the landslide susceptibility assessment.

The selected criteria, together with a brief description of the same, are given in Table 3, and they are shown in Figures 3-5.

The lithology classes are defined by the different types of the geological formation and they are accounted for in Table 4. 
Table 3. The conditioning factors' description.

\begin{tabular}{|c|c|c|}
\hline Category & Factor & Description \\
\hline \multirow{6}{*}{$\begin{array}{l}\text { Topography } \\
\text { (Figure 3) }\end{array}$} & Topo1 & $\begin{array}{l}\text { The elevation is a significant landslide conditioning factor because it controls several geologic and geomorphologic processes [64]. An elevation map is prepared } \\
\text { from the } 20 \times 20 \mathrm{~m} \text { digital elevation model (1: } 25,000 \text { scale with 10-m contour intervals) and grouped into } 6 \text { classes. }\end{array}$ \\
\hline & Topo2 & $\begin{array}{l}\text { The slope is widely used in landslide susceptibility studies since it is directly connected with the movement of landslide materials [49]. Specifically, shear stresses } \\
\text { on the slope material increases with the slope gradient and landslides are generally expected to occur on the steepest slopes. }\end{array}$ \\
\hline & Topo3 & $\begin{array}{l}\text { The aspect affects the slope material in an indirect relationship because the aspect determines the exposure of a landscape to rainfall and solar radiation, and } \\
\text { therefore, to the propensity of vegetation to grow, which in turn affects the soil stability. }\end{array}$ \\
\hline & Topo4 & $\begin{array}{l}\text { The topographic wetness index (TWI) describes the effect of topography on the location and size of the saturated areas of the runoff generation. It is defined as [65]: } \\
T W I=\ln \left(A_{S} / \tan \beta\right) \text {, where } A_{S} \text { is the catchment area and } \beta \text { is the slope angle measured in degrees. }\end{array}$ \\
\hline & Topo5 & $\begin{array}{l}\text { The stream power index (SPI) is the measure of the erosive power of flowing water based on the assumption that discharge is proportional to the specific } \\
\text { catchment area. The stream power index was calculated based on the formula given by Moore [66]. SPI }=A_{S} \times \tan \beta \text {, where } A_{S} \text { is the area of the specific } \\
\text { catchment and } \beta \text { is the local slope gradient measured in degrees. }\end{array}$ \\
\hline & Topo6 & $\begin{array}{l}\text { The sediment transport index }(\mathrm{STI}) \text { describes the tendency of the flow and can be used to depict the location of a potential erosion. It is calculated by using the } \\
\text { following formula: } S T I=\left(A_{S} / 22.13\right)^{0.6} \times(\sin \beta / 0.0896)^{1.3}, \text { where } A_{S} \text { is the area of the specific catchment and } \beta \text { is the local slope gradient measured in degrees. }\end{array}$ \\
\hline \multirow{6}{*}{$\begin{array}{l}\text { Environmental } \\
\quad \text { (Figure 4) }\end{array}$} & Env1 & $\begin{array}{l}\text { The soil type reflects the textures and compositions of the soil materials affecting the landslide occurrence [67]. The soil map was constructed from the Basic } \\
\text { Engineering National Soil Map at the scale 1:000,000, and was classified into fine-silt, course-loamy, fine-loamy, mixed-loamy, skeletal-loamy. }\end{array}$ \\
\hline & Env2 & $\begin{array}{l}\text { The drainage system of any area plays an important role in the slope stability particularly with respect to toe cutting and the bank erosion. The distance to the } \\
\text { river was created by using a topographical map and was calculated based on the Euclidean distance method in ArcGIS } 10.4 \text { and the obtained distances were } \\
\text { classified into }(<500),(500-1000),(1000-2000),(2000-3000) \text {, and }(>3000) \text { m classes. }\end{array}$ \\
\hline & Env3 & $\begin{array}{l}\text { Lithology. The underlying geology is part of the most significant factors for landslide modeling [68]. Different geology formations have different compositions } \\
\text { and structures which contribute to the strength of the material. The stronger rocks give more resistance to the driving forces as compared to the weaker rocks } \\
\text { and, hence, are less prone to landslides. The lithology structure of the study area includes } 18 \text { classes. }\end{array}$ \\
\hline & Env4 & $\begin{array}{l}\text { Distance to fault. The distance from the faults is calculated at } 100 \mathrm{~m} \text { intervals by using the geological map. Faults are the tectonic breaks that usually decrease the } \\
\text { rock strength. These dislocations may be responsible for triggering a large number of landslides. }\end{array}$ \\
\hline & Env5 & $\begin{array}{l}\text { The normalized difference vegetation index (NDVI). The NDVI map was produced from the Lands at } 8 \text { OLI imagery showing the surface vegetation coverage and } \\
\text { density in an image. }\end{array}$ \\
\hline & Env6 & $\begin{array}{l}\text { Rainfall is the most important triggering factor in landslides. Annual rainfall values are divided into the six classes, namely: }(620-690,691-760,761-830,831-900 \text {, } \\
901-970,971-1055 \mathrm{~mm}) \text {. }\end{array}$ \\
\hline \multirow{3}{*}{$\begin{array}{c}\text { Social } \\
\text { (Figure 5) }\end{array}$} & Soc1 & $\begin{array}{l}\text { Landslides may occur on the road and on the side of the slopes affected by roads. The distance to roads was created by using a topographical map and } \\
\text { calculated based on the Euclidean distance method in ArcGIS 10.4, and the obtained distances were classified into the }(<500),(500-1000),(1000-2000) \text {, } \\
(2000-3000) \text {, and }(>3000) \text { m classes. }\end{array}$ \\
\hline & Soc2 & $\begin{array}{l}\text { Distance to urban areas was created by using a topographical map and calculated based on the Euclidean distance method in ArcGIS 10.4, and the obtained } \\
\text { distances were classified into the }(<500),(500-1000),(1000-2000),(2000-3000) \text {, and }(>3000) \mathrm{m} \text { classes. }\end{array}$ \\
\hline & Soc3 & $\begin{array}{l}\text { Land use/cover is considered to be a factor in environmental protection. The data on the land use/cover were taken on the basis of the Corine Land Cover } 2006 \\
\text { (CLC2006) database, collected within the framework of the European Commission's CORINE (Coordination of Information on the Environment) program. The } \\
\text { land use also plays a significant role in the stability of the slope. The land covered with a forest regulates the continuous water flow and water infiltrates } \\
\text { regularly, whereas the cultivated land affects the slope stability due to the saturation of the covered soil. }\end{array}$ \\
\hline
\end{tabular}



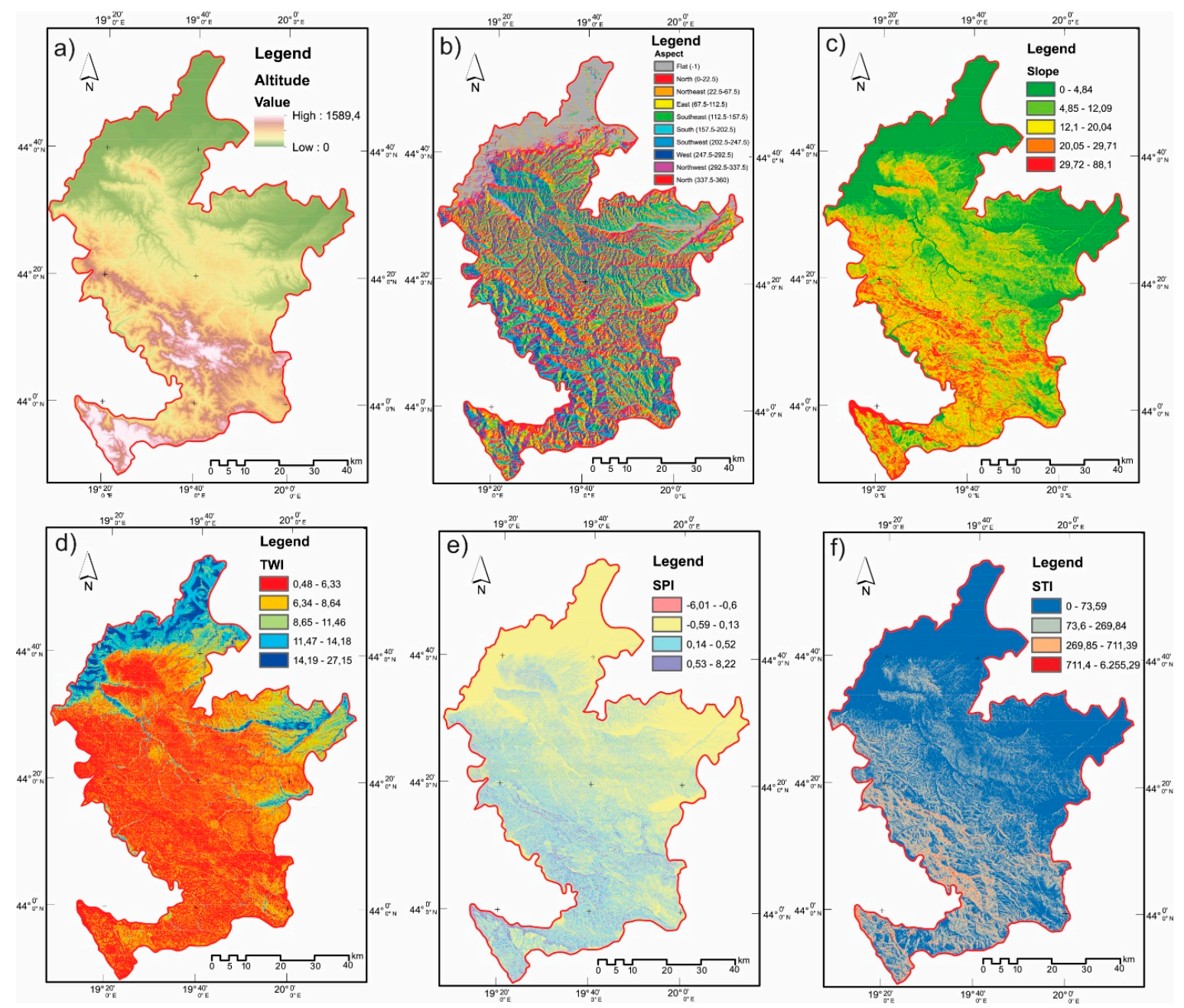

Figure 3. The topographical factors related to landslides: (a) the elevation; (b) the aspect; (c) the slope; (d) the topographic wetness index (TWI); (e) the stream power index (SPI); (f) the sediment transport index (STI). 

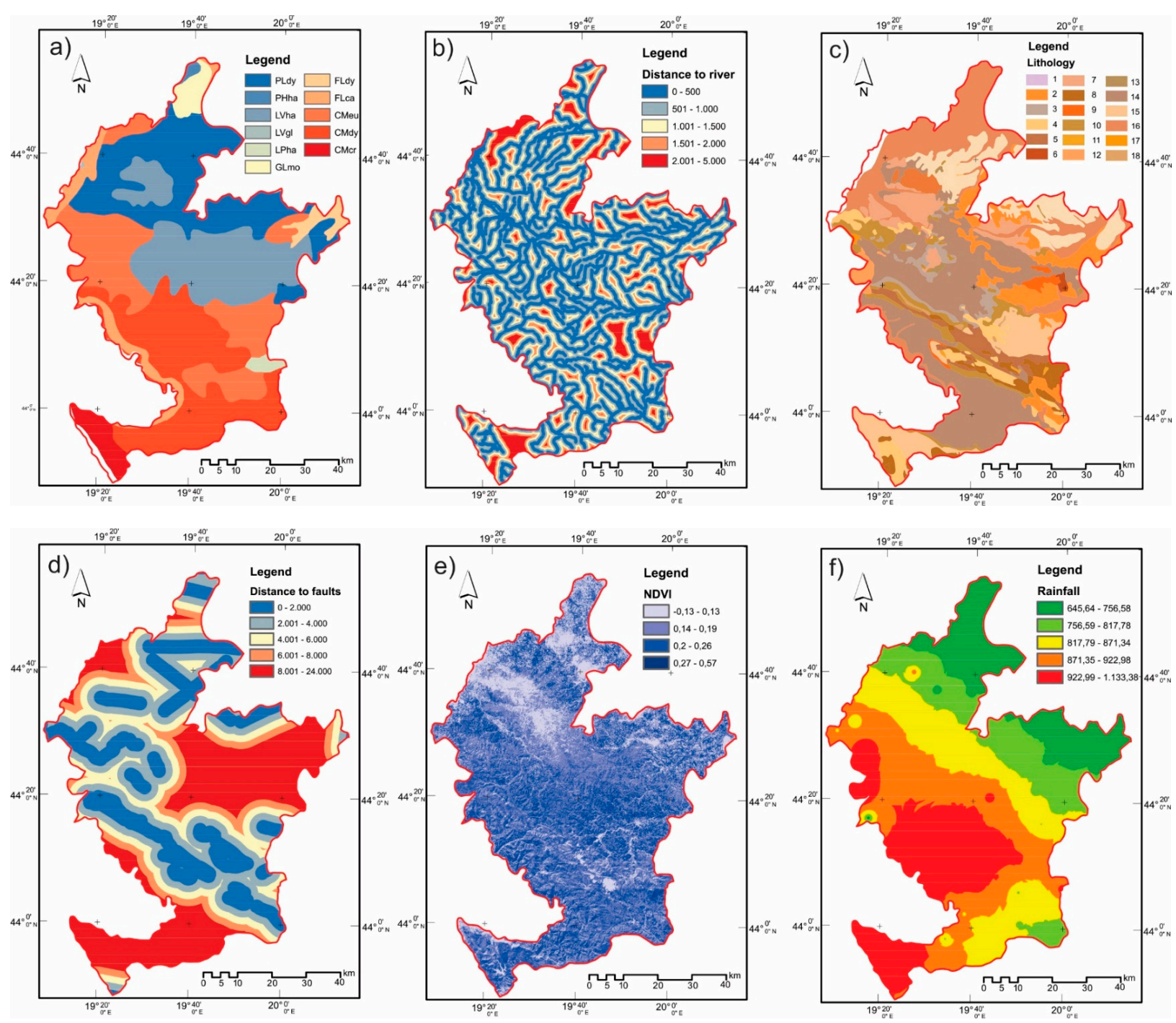

Figure 4. The environmental factors related to landslides: (a) the soil type, (b) the distance to the river, (c) lithology, (d) the distance to faults, (e) the NDVI, (f) rainfall. 


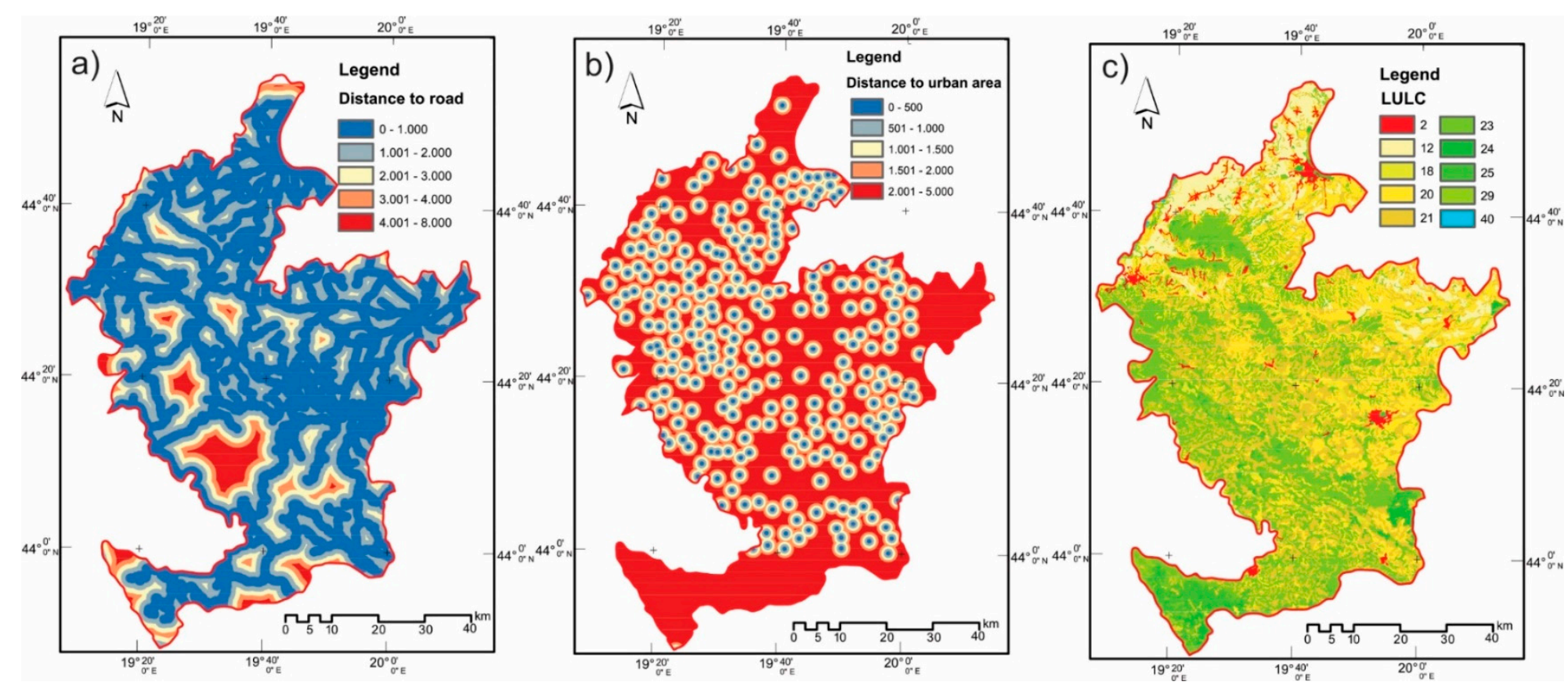

Figure 5. The social factors related to landslides: (a) the distance to roads, (b) the distance to urban areas, (c) the land use/cover. 
Table 4. The types of the geological formation of the study area.

\begin{tabular}{|c|c|c|c|}
\hline Class & Formation & Lithology & Geological Age \\
\hline 1 & Clastic sediment & Brackish deposits, clastic sediment, limestone, coal & Tortonian and Messinian \\
\hline 2 & Clastic sediment & Clastic and carbonate rocks, clastic sediment, limestone, metamorphic rock & Permian \\
\hline 3 & Limestone & Flysch and other basin deposits, limestone, clastic sedimentary rock, dolomite, mudstone & Upper Cretaceous \\
\hline 4 & Clastic sedimentary rock & Flysch and other basin deposits, clastic sedimentary rock, limestone & Upper Jurassic \\
\hline 5 & Clastic conglomerate & Lacustrine deposits, conglomerate, sandstone, siltstone, coal & Aquitanian and Burdigalian \\
\hline 6 & Sand & Lacustrine deposits, sand, clay, gravel, mudstone, coal, limestone & Pliocene \\
\hline 7 & Limestone & Marine clastic rocks, limestone, clastic sediment, coal & Langhian and Serravallian \\
\hline 8 & Ultramafic igneous rock & Ophiolite sequence, ultramafic igneous rock, gabbro, peridotite, serpentinite & Jurassic \\
\hline 9 & Clastic sediment & Platform carbonate rocks, clastic sediment, limestone & Permian and Triassic \\
\hline 10 & Limestone & Platform carbonate rocks, limestone, clastic sediment, dolomite & Triassic \\
\hline 11 & Gabbro & Plutonic rocks, gabbro, granite, quartz-monzonite & Jurassic \\
\hline 12 & Granodiorite & Plutonic rocks, granodiorite & Miocene and Oligocene \\
\hline 13 & Granite & Plutonic rocks, granite, granodiorite & Paleozoic \\
\hline 14 & Shale & Predominantly clastic rocks, shale, sandstone, conglomerate, limestone & Carboniferous to Permian \\
\hline 15 & Limestone & Predominantly platform carbonate rocks, limestone, dolomite, clastic sediment & Triassic \\
\hline 16 & Clastic sediment & Terrestrial deposits, clastic sediment, organic rich sediment, travertine & Quaternary \\
\hline 17 & Andenzite & Volcanic rocks, andenzite, pyroclastic rock & Neogene \\
\hline 18 & Trachite & Volcanic rocks, trachite, rhyolite, andesites, dacites & Triassic \\
\hline
\end{tabular}


The description of the soil types based on the codes is shown in Table 5.

Table 5. The description for the soil type.

\begin{tabular}{cc}
\hline Code/Value & Description \\
\hline Flca & Calcaric Fluvisol \\
Fldy & Dystric Fluvisol \\
CMcr & Chromic Cambisol \\
Cmdy & Dystric Cambisol \\
Cmeu & Eutric Cambisol \\
Glmo & Mollic Gleysol \\
Lpha & Haplic Leptosol \\
Lvgi & Gleyic Luvisol \\
Lvha & Haplic Luvisol \\
Pldy & Dystric Planosol \\
Phha & Haplic Phaeozem \\
\hline
\end{tabular}

The description of the land cover/land use based on the codes is shown in Table 6.

Table 6. The description for the land cover/land use.

\begin{tabular}{cccc}
\hline Code/Value & RGB & Code & Description \\
\hline $\mathbf{2}$ & $255,0,0$ & 112 & Discontinuous urban fabric \\
$\mathbf{1 2}$ & $255,255,168$ & 211 & Non-irrigated arable land \\
$\mathbf{1 8}$ & $230,230,77$ & 231 & Pastures \\
$\mathbf{2 0}$ & $255,230,77$ & 242 & Complex cultivation patterns \\
$\mathbf{2 1}$ & $230,204,77$ & 243 & Land principally occupied by agriculture, with \\
$\mathbf{2 3}$ & $128,255,0$ & 311 & significant areas of natural vegetation \\
$\mathbf{2 4}$ & $0,166,0$ & 312 & Broad-leaved forest \\
$\mathbf{2 5}$ & $77,255,0$ & 313 & Coniferous forest \\
$\mathbf{2 6}$ & $204,242,77$ & 321 & Mixed forest \\
$\mathbf{2 9}$ & $166,242,0$ & 324 & Natural grasslands \\
$\mathbf{4 0}$ & $0,204,242$ & 511 & Water courses \\
\hline
\end{tabular}

\subsection{GIS MCDA-BW Methodology}

This phase involves the standardization, expert work, weighting, summary analysis, the aggregation of all of the criteria to be considered in the decision-making process, and their validation as well.

Given the fact that the data were collected in different ways and that they have different formats, the first step implies that all the datasets have to be standardized and expressed in the units that can be compared. Based on the literature and the experts' experiences, the fuzzy concept applied in this study was used to standardize the data criteria. The fuzzy logic concept is flexible and suitable for the data modeling in which there are no exact boundaries of the elements belonging to the set, determined as either zero or one [69]. In such cases, the elements belonging to the set are defined on the basis of the degree of affiliation to a function (sigmoidal, J-shaped, linear or user-defined). Which membership functions will be used depends on the nature of the data and the experts' opinions.

In this case, with the criteria set whose elements have categorical values (the land cover use), the discrete classification in which the experts directly determined the values of the elements of the fuzzy sets was applied. With respect to the other criteria, which are the values of the gradual change from one location to another, the elements of the set were standardized by using the fuzzy concept based on the linear membership function. The scale ranging from 0 to 1 byte was used for the purpose of fuzzification, where zero stands for the least susceptibility, and one represents the most dangerous element of the set value in relation to the likelihood of the occurrence of the landslide (Table 7). 
Table 7. The fuzzification of the conditioning factors.

\begin{tabular}{|c|c|c|}
\hline Criteria & Membership Function & Control Points/Value Points \\
\hline Elevation & Gaussian & Midpoint 400 m; Spread 0.0001 \\
\hline Slope & Gaussian & Midpoint $22^{\circ} ;$ Spread 0.001 \\
\hline Aspect & Gaussian & Midpoint $160^{\circ}$; Spread 0.001 \\
\hline TWI & Small & Midpoint 12; Spread 5 \\
\hline SPI & Small & Midpoint 1.1; Spread 5 \\
\hline STI & Small & Midpoint 160; Spread 5 \\
\hline Soil & Discrete data & $\begin{array}{l}\text { FLdy, GLmo-0.1; PHha, PLdy-0.3; LVgl, Lpha-0.5; CMcr, } \\
\text { CMeu, CMdy-0.7; FLca, Lvha-0.9 }\end{array}$ \\
\hline Distance from river & Linear & Minimum 2000 m; Maximum 0 m \\
\hline Lithology & Discrete data & $\begin{array}{c}\text { Class } 1-0.05 \text {; Class } 2-0.11 \text {; Class } 3-0.16 \text {; Class } 4-0.22 ; \\
\text { Class } 5-0.28 \text {; Class } 6-0.33 \text {; Class } 7-0.39 \text {; Class } 8-0.45 ; \\
\text { Class } 9-0.5 \text {; Class 10-0.55; Class 11-0.6; Class 12-0.65; } \\
\text { Class 13-0.7; Class 14-0.75; Class 15-0.8; Class 16-0.85; } \\
\text { Class 17-0.9; Class 18-0.95. }\end{array}$ \\
\hline Distance to fault & Linear & Minimum 2000 m; Maximum 0 m \\
\hline NDVI & Linear & Minimum 0.5; Maximum 0.1 \\
\hline Rainfall & Linear & Minimum 600 mm; Maximum 1200 mm \\
\hline Distance to roads & Linear & Minimum 2000 m; Maximum 0 m \\
\hline Distance to urban & Linear & Minimum $5000 \mathrm{~m}$; Maximum $0 \mathrm{~m}$ \\
\hline Land cover use & Discrete data & $\begin{array}{r}(511-512)-0 ;(311-313)-0.1 ;(331-332,321-335)-0.3 ; \\
(221-223 ; 231)-0.5 ;(211-223)-0.7 ;(241-244 ; 112)-0.9\end{array}$ \\
\hline
\end{tabular}

After standardization, it is necessary for decision-makers to define the significant factors of particular criteria by using the appropriate coefficient weights (weights) or the criteria weights. The BWM was used for the analysis of the factors carried out by the experts. This research included six experts. Having defined the evaluation clusters/criteria within the framework of the clusters and each group of the criteria, the experts also determined the best $(B)$ and the worst $(\mathrm{W})$ clusters/criteria. On this basis, the experts determined the $\mathrm{BO}$ and the $\mathrm{OW}$ vectors, in which the preferences of the $\mathrm{B}$ and the $\mathrm{W}$ over the clusters/criteria were considered for the remaining clusters/criteria from the defined set. The evaluation of the clusters/criteria was carried out by using the scale [1,9]: 1—a very low influence; 2-a low influence; .. ; 8-a high influence; 9-a very high influence. The $\mathrm{BO}$ and the OW vectors are presented in Table 8.

Table 8. The Best-to-Others (BO) and the Others-to-Worst $(\mathrm{OW})$ vectors obtained by the experts' evaluation.

\begin{tabular}{|c|c|c|c|}
\hline \multicolumn{4}{|c|}{ Clusters } \\
\hline Best: C1 (Topography) & Expert evaluation & Worst: C3 (Social) & Expert evaluation \\
\hline C2 (Environmental) & $2 ; 2 ; 3 ; 2 ; 3 ; 2 ; 3$ & C1 (Topography) & $3 ; 4 ; 3 ; 3 ; 4 ; 5 ; 4$ \\
\hline C3 (Social) & $3 ; 4 ; 3 ; 3 ; 4 ; 5 ; 4$ & C2 (Environmental) & $2 ; 4 ; 3 ; 3 ; 4 ; 5 ; 4$ \\
\hline \multicolumn{4}{|c|}{ C1 (Topography) } \\
\hline Best: C11 (Slope) & Expert evaluation & Worst: C13 (Aspect) & Expert evaluation \\
\hline C12 (TWI) & $3 ; 3 ; 4 ; 2 ; 3 ; 3 ; 3$ & C11 (Slope) & $9 ; 8 ; 9 ; 8 ; 9 ; 9 ; 9$ \\
\hline C13 (Aspect) & $9 ; 8 ; 9 ; 8 ; 9 ; 9 ; 9$ & C12 (TWI) & $3 ; 3 ; 4 ; 3 ; 3 ; 4 ; 3$ \\
\hline C14 (Elevation) & $2 ; 2 ; 3 ; 2 ; 2 ; 2 ; 3$ & C14 (Elevation) & $4 ; 4 ; 3 ; 5 ; 4 ; 4 ; 4$ \\
\hline C15 (STI) & $5 ; 5 ; 6 ; 5 ; 4 ; 5 ; 5$ & C15 (STI) & $2 ; 2 ; 2 ; 2 ; 2 ; 3 ; 2$ \\
\hline C16 (SPI) & $4 ; 4 ; 5 ; 4 ; 4 ; 3 ; 4$ & C16 (SPI) & $3 ; 2 ; 4 ; 3 ; 3 ; 2 ; 4$ \\
\hline \multicolumn{4}{|c|}{ C2 (Environmental) } \\
\hline Best: C21 (Rainfall) & Expert evaluation & $\begin{array}{c}\text { Worst: } \mathrm{C} 23 \text { (Distance to } \\
\text { river) }\end{array}$ & Expert evaluation \\
\hline C22 (Soil type) & $2 ; 3 ; 3 ; 2 ; 2 ; 3 ; 3$ & C21 (Rainfall) & $4 ; 5 ; 4 ; 5 ; 5 ; 5 ; 5$ \\
\hline C23 (Distance to river) & $4 ; 5 ; 4 ; 5 ; 5 ; 5 ; 5$ & C22 (Soil type) & $2 ; 3 ; 3 ; 4 ; 3 ; 4 ; 3$ \\
\hline C24 (Lithology) & $2 ; 2 ; 2 ; 2 ; 2 ; 2 ; 3$ & C24 (Lithology) & $3 ; 2 ; 4 ; 4 ; 3 ; 3 ; 5$ \\
\hline C25 (NDVI) & $5 ; 4 ; 5 ; 5 ; 4 ; 4 ; 5$ & C25 (NDVI) & $3 ; 2 ; 2 ; 3 ; 2 ; 2 ; 3$ \\
\hline C26 (Distance to fault) & $5 ; 4 ; 5 ; 6 ; 4 ; 4 ; 5$ & C26 (Distance to fault) & $4 ; 3 ; 5 ; 4 ; 2 ; 3 ; 4$ \\
\hline \multicolumn{4}{|c|}{ C3 (Social) } \\
\hline Best: C31 (Land use/cover) & Expert evaluation & $\begin{array}{c}\text { Worst: C33 (Distance to } \\
\text { urban areas) }\end{array}$ & Expert evaluation \\
\hline C32 (Distance to roads) & $2 ; 2 ; 3 ; 2 ; 3 ; 2 ; 3$ & C31 (Land use/cover) & $2 ; 3 ; 3 ; 3 ; 3 ; 4 ; 4$ \\
\hline C33 (Distance to urban areas) & $2 ; 3 ; 3 ; 3 ; 3 ; 3 ; 2$ & C32 (Distance to roads) & $2 ; 3 ; 2 ; 3 ; 3 ; 2 ; 3$ \\
\hline
\end{tabular}


Using Equations (4) and (7) we obtain the average $\mathrm{BO}$ and OW vectors (Table 9).

Table 9. The average $\mathrm{BO}$ and $\mathrm{OW}$ vectors.

\begin{tabular}{|c|c|c|c|}
\hline \multicolumn{4}{|c|}{ Clusters } \\
\hline Best: C1 (Topography) & Average value & Worst: C3 (Social) & Average value \\
\hline C2 (Environmental) & 2.43 & C1 (Topography) & 3.71 \\
\hline C3 (Social) & 3.71 & C2 (Environmental) & 3.57 \\
\hline \multicolumn{4}{|c|}{ C1 (Topography) } \\
\hline Best: C11 (Slope) & Average value & Worst: C13 (Aspect) & Average value \\
\hline C12 (TWI) & 3.00 & C11 (Slope) & 8.71 \\
\hline C13 (Aspect) & 8.71 & C12 (TWI) & 3.29 \\
\hline C14 (Elevation) & 2.29 & C14 (Elevation) & 4.00 \\
\hline C15 (STI) & 5.00 & C15 (STI) & 2.14 \\
\hline C16 (SPI) & 4.00 & C16 (SPI) & 3.00 \\
\hline \multicolumn{4}{|c|}{ C2 (Environmental) } \\
\hline Best: C21 (Rainfall) & Average value & $\begin{array}{c}\text { Worst: } \mathrm{C} 23 \text { (Distance to } \\
\text { river) }\end{array}$ & Average value \\
\hline C22 (Soil type) & 2.57 & C21 (Rainfall) & 4.71 \\
\hline C23 (Distance to river) & 4.71 & C22 (Soil type) & 3.14 \\
\hline C24 (Lithology) & 2.14 & C24 (Lithology) & 3.43 \\
\hline C25 (NDVI) & 4.57 & C25 (NDVI) & 2.43 \\
\hline C26 (Distance to fault) & 4.71 & C26 (Distance to fault) & 3.57 \\
\hline \multicolumn{4}{|c|}{ C3 (Social) } \\
\hline Best: C31 (Land use/cover) & Average value & $\begin{array}{c}\text { Worst: C33 (Distance to } \\
\text { urban areas) }\end{array}$ & Average value \\
\hline C32 (Distance to roads) & 2.43 & C31 (Land use/cover) & 3.14 \\
\hline C33 (Distance to urban areas) & 2.71 & C32 (Distance to roads) & 2.57 \\
\hline
\end{tabular}

On the basis of the $\mathrm{BO}$ and the OW vectors for each group of the clusters/criteria (Table 8), the optimal values of the weight coefficients of the clusters/criteria were calculated. Table 9 displays the four $\mathrm{BO}$ or OW vectors, which means that the four models (12) were formed for calculating the optimal values of the weight coefficients of the clusters/criteria:

\begin{tabular}{|c|c|c|c|}
\hline $\begin{array}{l}\text { Model } 1 \text { (Clusters) } \\
\min \xi\end{array}$ & $\begin{array}{l}\text { Model } 2 \text { (Socia } \\
\min \xi\end{array}$ & & \\
\hline s.t. & s.t. & & \\
\hline 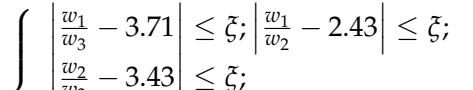 & $\int\left|\begin{array}{l}\frac{w_{1}}{w_{3}}-2.71 \\
\frac{w_{2}}{w_{2}}-2.57\end{array}\right|$ & $\begin{array}{l}\leq \xi \\
\leq \xi\end{array}$ & $\leq \xi$ \\
\hline$\sum_{j=1}^{3} w_{j}=1$ & $\sum_{j=1}^{3} w_{j}=1$ & & \\
\hline$w_{j} \geq 0, \forall j=1,2,3$ & $w_{j} \geq 0, \forall j=$ & $=1,2,3$ & \\
\hline---------------- & ------ & -------- & --- \\
\hline $\begin{array}{l}\text { Model } 3 \text { (Topographical) } \\
\min \xi\end{array}$ & $\begin{array}{l}\text { Model } 3 \text { (Envir } \\
\min \xi\end{array}$ & ronmental) & \\
\hline s.t. & s.t. & & \\
\hline$\frac{w_{1}}{w_{3}}-8.71 \leq \xi$ & $\frac{w_{2}}{w_{3}}-3.14$ & $\leq \xi$ & \\
\hline$\frac{w_{2}}{w_{3}}-3.29 \mid \leq \xi$ & $\frac{w_{4}}{w_{3}}-3.43$ & $\leq \xi$ & \\
\hline$\frac{w_{4}}{w_{3}}-4|\leq \xi ;| \frac{w_{5}}{w_{3}}-2.14 \mid \leq \xi$ & $\frac{w_{5}}{w_{3}}-2.43$ & $\leq \xi ;\left|\frac{w_{6}}{w_{3}}-3.57\right|$ & $\leq \xi$ \\
\hline$\frac{w_{6}}{w_{3}}-3 \leq \xi$ & $\frac{w_{1}}{w_{2}}-2.57$ & $\leq \xi ;\left|\frac{w_{1}}{w_{3}}-4.71\right|$ & $\leq \xi$ \\
\hline$\left|\frac{w_{1}}{w_{2}}-3\right| \leq \xi ;\left|\frac{w_{1}}{w_{4}}-2.29\right| \leq \xi ;$ & $\frac{w_{1}}{w_{4}}-2.14$ & $\leq \xi ;\left|\frac{w_{1}}{w_{5}}-4.57\right|$ & $\leq \xi$ \\
\hline $\begin{array}{l}\left|\frac{w_{1}}{w_{5}}-5\right| \leq \xi ;\left|\frac{w_{1}}{w_{6}}-4\right| \leq \xi \\
\sum_{j=1}^{6} w_{j}=1\end{array}$ & $\begin{array}{l}\left|\frac{w_{1}}{w_{6}}-4.71\right| \\
\sum_{j=1}^{6} w_{j}=1\end{array}$ & $\leq \xi$ & \\
\hline$w_{j} \geq 0, \forall j=1$ & $w_{j} \geq 0, \forall j=$ & $=1,2$. & \\
\hline
\end{tabular}


Based on the above models, the optimal values of the weight coefficients were obtained as demonstrated in Table 10.

Table 10. The optimal values (weights) of the criteria.

\begin{tabular}{cccc}
\hline Clusters/Criteria & Local Weights & Global Weights & Rank \\
\hline Topography & 0.5489 & - & 1 \\
\hline Elevation & 0.1927 & 0.1058 & 3 \\
Slope & 0.4166 & 0.2287 & 1 \\
Aspect & 0.0450 & 0.0247 & 13 \\
TWI & 0.1471 & 0.0807 & 4 \\
SPI & 0.1103 & 0.0606 & 7 \\
STI & 0.0883 & 0.0484 & 9 \\
\hline Environmental & 0.3283 & - & 2 \\
\hline Soil type & 0.1776 & 0.0583 & 8 \\
Distance to river & 0.0549 & 0.0180 & 15 \\
Lithology & 0.2133 & 0.0700 & 5 \\
Distance to fault & 0.0969 & 0.0318 & 12 \\
NDVI & 0.0999 & 0.0328 & 11 \\
Rainfall & 0.3574 & 0.1173 & 2 \\
\hline Social & 0.1229 & - & 3 \\
\hline Distance to roads & 0.3038 & 0.0373 & 10 \\
Distance to urban areas & 0.1592 & 0.0196 & 14 \\
Land use/cover & 0.5370 & 0.0660 & 6 \\
\hline
\end{tabular}

Table 10 presents the global and the local values of the weight coefficients of the criteria. The global weights of the criteria were obtained by multiplying the weight coefficients of the clusters by the weight coefficients of the sub-criteria. The global weight criteria continue to be used for the evaluation of the alternatives in the multi-criteria model [70].

By solving Model (11), the values of $\xi^{*}$ are obtained, which are as follows: $\xi^{*}$ Clusters $=0.75792$, $\xi^{*} C_{\text {Topo }}=0.02467, \xi^{*} C_{\text {Envir }}=0.09899$ and $\xi^{*} C_{S o c}=0.66228$. The values of $\xi^{*}$ are used to determine the consistency ratio, Equation (16). Since the value of $a_{B W}$ was obtained on the basis of the experts' aggregated decisions, the values of the consistency index $\xi$ are impossible to predefine. By applying Equation (15), the values of the consistency index $(\xi)$ were defined, as shown in Table 11. As seen in Table 11, the CR values are satisfactory.

Table 11. The consistency index and the consistency ratio of the best-worst methodology (BWM).

\begin{tabular}{ccccc}
\hline Level of the Criteria & $C_{\text {Clusters }}$ & $C_{\text {Topo }}$ & $C_{\text {Envir }}$ & $C_{\text {Soc }}$ \\
\hline$a_{B W}$ & 3.71 & 8.71 & 4.71 & 2.71 \\
$\mathrm{CI}(\max \xi)$ & 6.98 & 13.41 & 8.32 & 5.59 \\
$C R$ & 0.108 & 0.001 & 0.012 & 0.118 \\
\hline
\end{tabular}

\subsection{Aggregation by Applying a Weighted Linear Combination}

The weighted linear combination (WLC) method is used in the process of the criteria map aggregation. In addition, it is compensatory, meaning that the low scores in one criterion can be compensated for by the high scores in another, which is desired for this particular decision problem [71]. For these reasons, the WLC was selected as the aggregation method. The weighted linear combination (WLC) method multiplies each fuzzy standardized criteria map (i.e., each raster cell $20 \times 20 \mathrm{~m}$ ) by the criteria weights, thus obtaining different variations from the GIS-MCDA-BW method, and then sums the results. The mathematical expression for calculating the suitability index in the WLC is given as follows (17):

$$
S=\sum w_{i} x_{i}
$$


where $S$ is the suitability index, $w_{i}$ is the normalized value of the factor weight, and $x_{i}$ is the criterion score of the factor $i$.

Based on the adopted criteria and the determination of their weights, and according to the three scenarios described in the previous part, the WLC is used to execute the aggregation map of the criteria in the final landslide susceptibility map, which is presented in the same fuzzy value range from 0 to 1 . Finally, the landslide susceptibility index is calculated by using the defuzzification algorithm by the standard deviation method from the reclassify Spatial Analyst Tools ArcGIS 10.4 software release [72]. Based on this, each cell is classified into five categories and receives a new value from 1 to 5, representing the Landslide Susceptibility Index (LSI). The results of the landslide susceptibility assessment are given in the maps displayed in Figure 6. Value 1 is the area with the least probability of a landslide occurrence, whereas Value 5 represents the areas with the highest probability of a landslide occurrence.

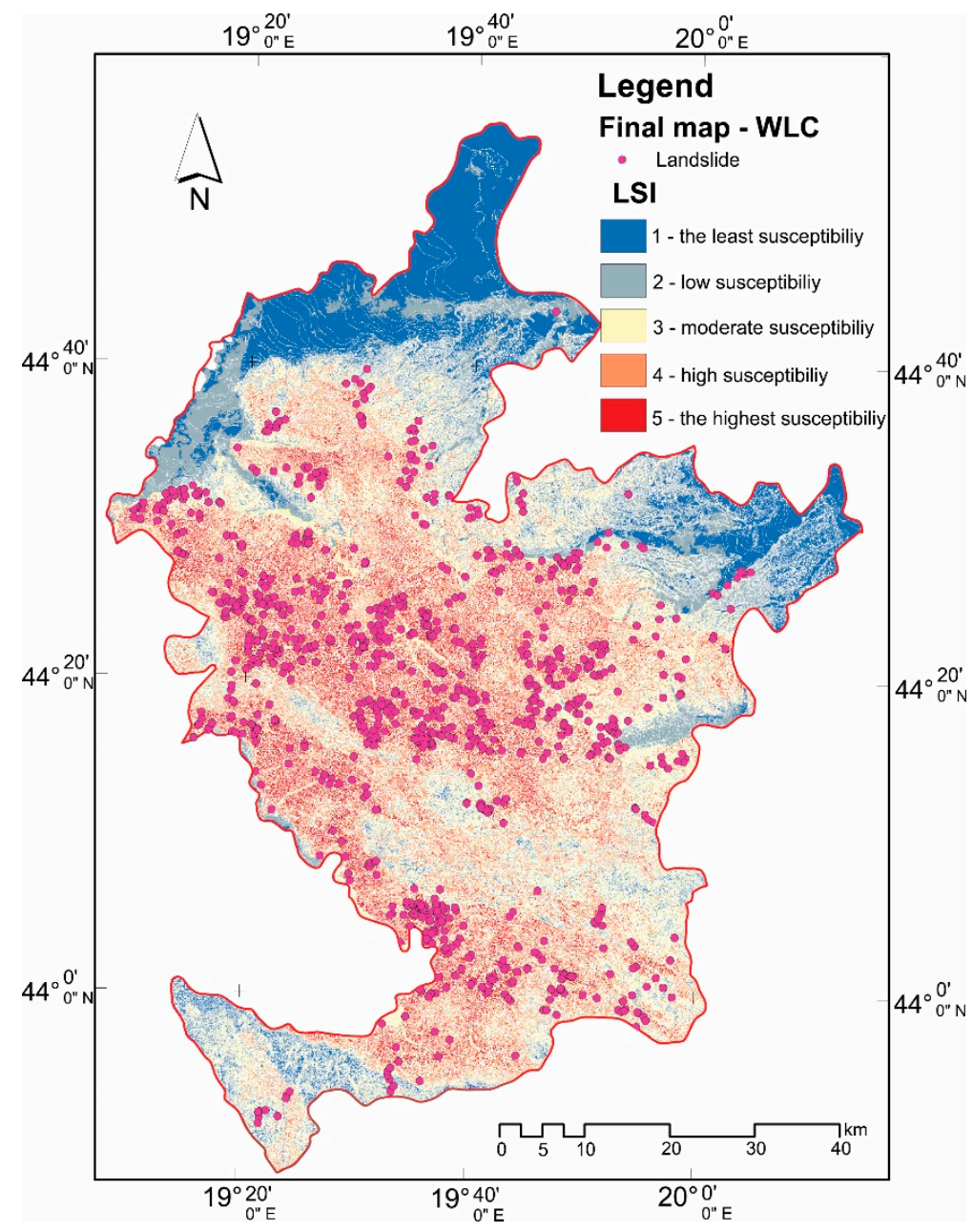

Figure 6. The final landslide susceptibility map created by applying the WLC aggregation method.

\subsection{Aggregation by Applying Ordered Weighted Averaging}

Ordered weighted averaging (OWA) is a class of multicriteria operators, which was given quantifier-guided aggregation [73]. In this method, the first set of weights controls the relative contribution of a specific criterion, whereas the second set of weights controls the order of the aggregation of the weighted criteria [74].

The OWA provides a tool for generating a wide range of decision strategies in a decision strategy analysis by applying a set of order weights to the criteria ranked in order on a location-by-location (object-by-object) basis. The order weights process is central to the OWA combination procedures. The 
number of order weights is equal to the number of the criteria and must sum to one. The position of the set of order weights can be identified in the multi-criteria decision analysis based on the trade-off and risk concepts $[75,76]$.

For a given set of $n$ criterion (attributes) maps, an OWA operator can be defined as the following function [77]:

$$
\operatorname{OWA}_{i}\left(a_{i 1}, a_{i 2}, \ldots, a_{i n}\right)=\sum_{j=1}^{n} v_{j} z_{i j}
$$

where:

$v=\left[v_{1}, v_{2}, \ldots, v_{n}\right]$ 一the set of the order weights

$A i=\left[a_{i 1}, a_{i 2} \ldots, a_{i n}\right]$ 一 the set of the standardized criterion value

$z_{i j}=\left[z_{i 1}, z_{i 2} \ldots, z_{i n}\right]$ 一the sequence obtained by reordering the criterion values $a_{i 1}, a_{i 2} \ldots, a_{i n}$.

By using the reclassify tool in Spatial Analyst Tools ArcGIS 10.4 software, each cell of the final map is classified into five categories and receives a new value from one to five, representing the LSI. The results of the landslide hazard assessment are given in the maps shown in Figure 7. Value 1 is the area with the least probability of a landslide occurrence, whereas Value 5 represents the areas with the highest probability of a landslide occurrence.

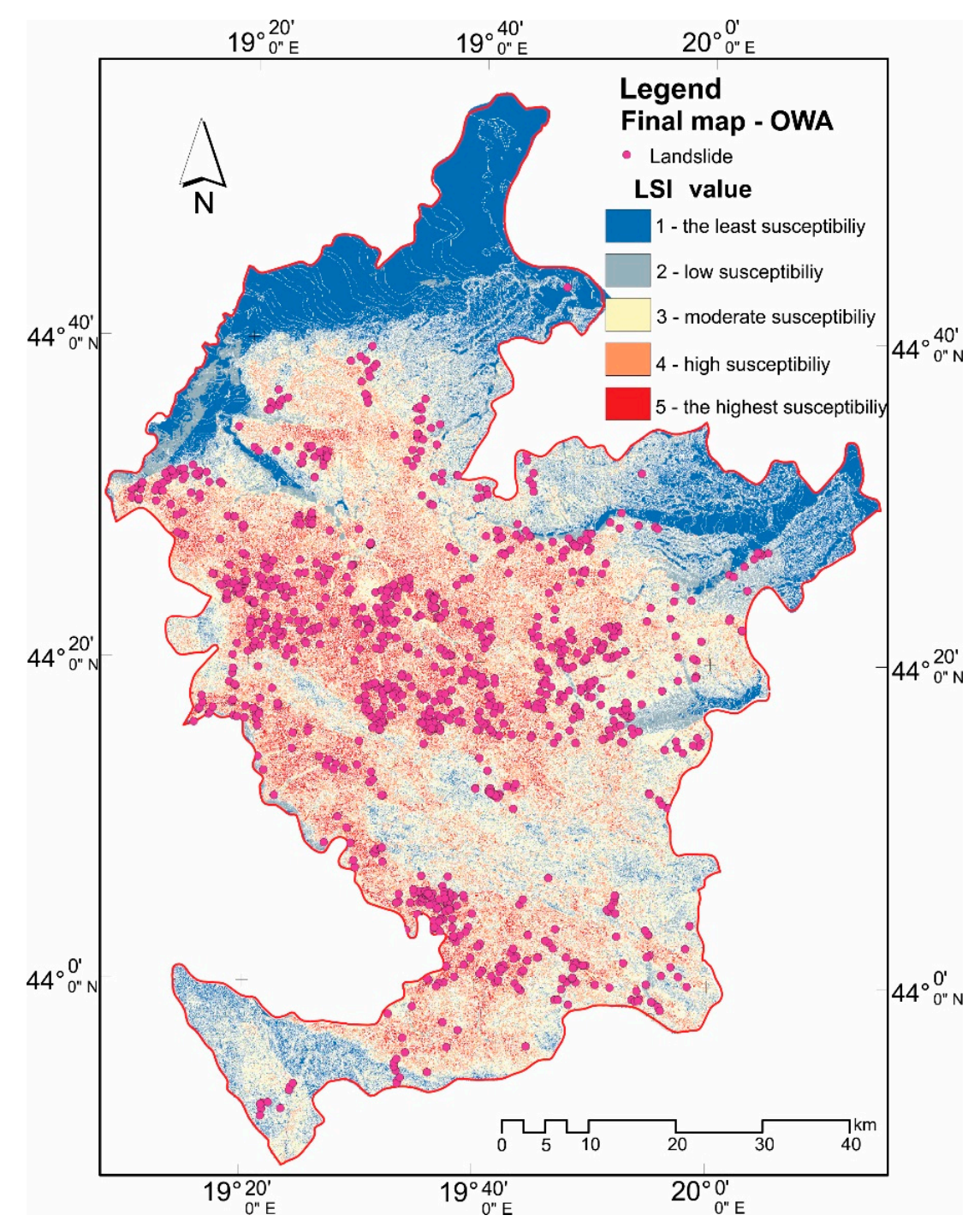

Figure 7. The final landslide susceptibility map created by using the OWA aggregation method. 


\subsection{Validation}

The validation of landslide susceptibility maps (LSMs) is an essential step in the modeling process. The capability of the WLC and the OWA methods was evaluated by applying a non-dependent threshold approach: the receiver operating characteristic (ROC) curve. The area under the curve (AUC) is the synthetic index calculated for the ROC curves, and the same has generally been used in several types of research studies to evaluate the accuracy of the landslide susceptibility map [78]. The AUC is the probability that a positive event is classified as positive by doing the test given all the possible values of the test. The ROC curves are generated by XLSTAT (statistical software for Microsoft Excel) and represent the evolution of the proportion of true positive cases (also called sensitivity) as a function of the proportion of false positive cases (corresponding to 1 minus the specificity).

Furthermore, the model of this article is based on expert knowledge and all of the historical landslide occurrence samples are taken into account. In this study, the historical landslide sites were randomly divided into the training sets $(70 \%$ of the total) and the validation sets $(30 \%)$.

The final results of the fifteen landslide susceptibility maps (the maps generated by the WLC and the OWA aggregation method of the best-worst model) were validated by being compared with the existing landslides locations, using the success rate and the prediction rate methods. The success-rate results were obtained based on the comparison of the landslide grid cells in the training dataset with the fifteen landslide susceptibility maps. The success rate measures how the results of the landslide susceptibility analysis fit the training dataset. This method divides the area of the landslide susceptibility map into five classes, ranging from the highest to the lowest LSI values (Figure 7). The success rate method uses the training dataset, so it may not be an appropriate method to evaluate the predictability of the landslide susceptibility models.

The prediction rate can explain how well the landslide susceptibility models and the landslide conditioning factors predict a landslide occurrence. In this study, the prediction rate results were obtained by comparing the landslide grid cells in the validation dataset with the fifteen landslide susceptibility maps.

The area under the prediction rate ROC curve (AUC) was calculated. Figure 8 shows the prediction rate results of the fifteen landslide susceptibility maps obtained from the WLC and the OWA aggregation methods for the GIS-MCDA-BW methodology.

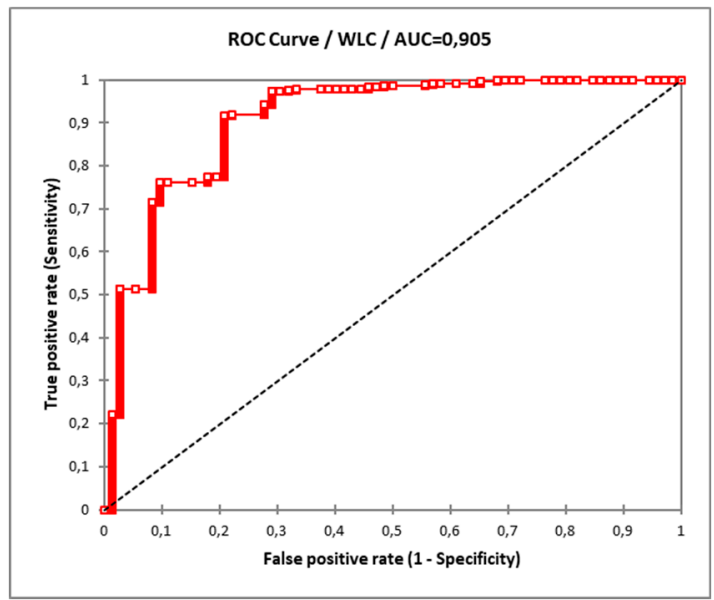

(a)

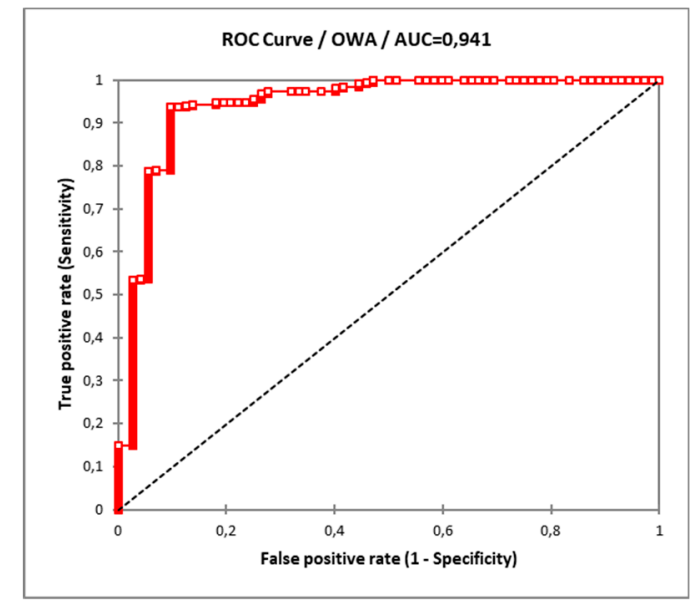

(b)

Figure 8. The receiver operating characteristic (ROC) curves for: (a) the WLC aggregation, (b) the OWA aggregation methods.

According to validation results, all of the final landslide susceptibility maps were considered to have the most acceptable and representable appearances (AUC > 0.9). The OWA aggregation technique exposed the overall best cross-validated performance, followed by the weighted linear 
combination method. With its value AUC $=0.941$, the OWA aggregation technique is confirmed to have a very high accuracy of validation (Figure $8 \mathrm{~b}$ ). Also, both the visual assessment and the quantitative validation-through the ROC curve-agreed with the WLC aggregation technique as an excellent performing model approach with an AUC value 0.905 (Figure 8a).

\section{Discussion}

The main goal of this work was to investigate the use a novel MCDA-GIS BW technique for the purpose of evaluating landslide susceptibility mapping, which is constructed by the WLC and the OWA aggregation methods for the GIS-MCDA-BW methodology in the case study of Western Serbia.

The considered conditioning factors did not have the same contribution to a landslide occurrence, for which reason decision-makers should define the importance of each conditioning factor by using appropriate weight coefficients. The WLC and the OWA methods require weight normalization. After determining the weight coefficients of the conditioning factors, the hybrid GIS MCDA best-worst method was used to calculate the normalized weight conditioning factors. Finally, the WLC and the OWA methods were subsequently used in the GIS environment in order to obtain the final landslide susceptibility map.

According to the determination of the importance of the differently used factors for landslide susceptibility mapping, the results of the current study have shown that the most important conditioning factor is the slope, which is only followed by annual rainfall, the elevation, and the TWI [49,79-81].

As the slope increases, the strain on the soil or another unconsolidated material generally increases as well. Due to the generally lower shear stress associated with low gradients, mild slopes are expected to have a low frequency of landslides. However, steep natural slopes resulting from the excavation of rocks may not be susceptible to severe landslides. For the most part, landslides occurred in the eastern and south-eastern facing of the slope, which is in accordance with the research reported by Pourghasemi et al. [31].

In fact, landslide susceptibility can be considered as a comprehensive assessment of the basic conditions of a disaster and a comprehensive measurement of the existing landslide characteristics, without considering the dynamic predisposing factors, such as extreme climatic conditions and human engineering activities, and without involving the problem of when a landslide will occur. Therefore, it is different from a timely warning or sequence analyses, without taking the time, frequency, and intensity of local landslides into consideration. The additional objective of this paper was to find spatial trends in the relationship between landslide susceptibility mapping and annual rainfall in the study area. However, each landslide event has a different precipitation and duration. Therefore, the uniformity of extreme rainfall and its duration cannot be taken as a conditioning factor. Finally, extreme rainfall and its duration will be used as the key factor in landslide susceptibility mapping in a future study.

In addition to the foregoing, the TWI is one of the conditioning factors having a highly significant impact on landsliding. The TWI describes the effect of topography on the location and size of the saturated areas of the runoff generation. The TWI shows the diversity and complexity of the topographical landslide surface, highlighting the areas of preferential landslide drainage and relatively dry areas within its borders.

On the other hand, the distance to rivers and the distance to urban areas referred to in this study had the lowest importance for a landslide occurrence. This is partly in agreement with the findings reported in Hong et al. [82] and Akgun et al. [14], even though the distance from faults was reported as the main effective factor [48,83-87].

According to the determination of the importance of the used methodology, compared with the AHP method as the most commonly used heuristic and index-based approach in the literature referred to for the purpose of determining the weight coefficients, the best-worst method requires significantly fewer pairwise comparisons. In addition, the values of the weight coefficients obtained 
by the BW method are more reliable because comparison in the BW method is carried out with a higher consistency ratio compared with the AHP method [88]. Furthermore, the consistency ratio for the majority of the MCDM models (e.g., the AHP) is the test of whether the comparison of criteria is consistent or not; in the BW method, the consistency ratio is used to determine the level of confidence since the outputs from the BW are always consistent. Ultimately, the BW model only uses integers for the pairwise comparison of criteria as opposed to the other MCDM methods (e.g., the AHP), which also require the use of fractional numbers.

\section{Conclusions}

A landslide is considered to be one of the most disastrous hazards throughout the world. Every year, it results in the death of many people and large economic loss. In order to reduce the landslide-resulting loss, many scholars have joined forces in conducting research studies on the cause and prediction of landslides. The landslide susceptibility map is the first step in the development of landslide risk management and local governments are expected to use it for effective management planning purposes. Therefore, the GIS-MCDA-BW technique was used in this study in the section dealing with the determination of the weights, namely with the significance of each criterion, and the WLC and the OWA techniques were used to sum the weights and finally to identify the landslide susceptibility areas. The connection between the tools was possible in the ArcGIS software environment by using the ESRI firm's ArcGIS 10.4 software.

For the landslide susceptibility mapping, field survey, high-resolution images, and aerial photo interpretation methods were used to make the landslide inventory map. A total of 15 conditioning factors were prepared, such as elevation, slope, aspect, TWI, STI, SPI, NDVI, distance to faults, distance to roads, distance to the river, distance to urban areas, rainfall, land cover/use, lithology, and soil type. The final landslide susceptibility maps were confirmed to have a very high accuracy of the validation represented by using the AUC value.

It is possible to draw the following conclusions. First, the proposed method can use both qualitative and quantitative methods to perform landslide susceptibility maps. Expert knowledge can fully be used, which differs from statistical learning. Second, the validation process was performed based on the comparison of historical landslide locations with the different landslide-susceptible zones on the final map. The higher AUC values demonstrate the effectiveness of the proposed method. Specifically, according to the resultant LSI scales, $776.3 \mathrm{~km}^{2}(15 \%), 1126 \mathrm{~km}^{2}(21.8 \%)$, and $1120 \mathrm{~km}^{2}$ $(21.7 \%)$ of the study area were labelled with "the highest", "high", and "moderate" susceptibility, respectively, which proves that the tested area is mostly located in the landslide-prone areas. These highly susceptible zones are located on the most rugged slopes, which are the area with the greatest rainfall and with a higher elevation and highland reliefs.

The main recommendations for the further application of this model are those pointing out its accessible mathematical apparatus and the stability (consistency) of its solution, as well as the possibility of combining it with other methods, especially in the section related to the determining of the weight criteria. A future improvement of the GIS MCDA model may be introduced by applying a multiplicative full consistency method $[84,85]$ or the intervals of fuzzy numbers in order to determine the parameters of the conditioning factors. In addition to the fuzzy technique, grey theory is yet another suitable tool to be applied to the conditions of uncertainty and ambiguity.

Author Contributions: S.D. and L.G. prepared the data layers, figures, and tables; D.P. performed the experiments and analyses. L.G. and S.D. supervised the research, finished the first draft of the manuscript, edited and reviewed the manuscript, and contributed to the model construction and verification.

Funding: This research received no external funding.

Acknowledgments: This work was supported by the VA/TT/3/17-19 research project entitled: “GIS Modeling of Risk Assessment of Disasters and Catastrophes in the Function of the Third Mission of the Army of Serbia" by the Ministry of Defense of the Republic of Serbia. 
Conflicts of Interest: The authors declare no conflicts of interest. The funders had no role in the design of the study, in the collection, analyses, or interpretation of the data, in the writing of the manuscript, and in the decision to publish the results.

\section{References}

1. Pourghasemi, H.R.; Jirandeh, A.G.; Biswajeet, P.; Xu, C.; Gokceoglu, C.; Pradhan, B.; Xu, C.; Gokceoglu, C. Landslide susceptibility mapping using support vector machine and GIS at the Golestan Province, Iran. J. Earth Syst. Sci. 2013, 122, 349-369. [CrossRef]

2. Santacana, N.; Baeza, B.; Corominas, J.; De Paz, A.; Marturiá, J. A GIS-based multivariate statistical analysis for shallow landslide susceptibility mapping in La Pobla de Lillet Area (Eastern Pyrenees, Spain). Nat. Hazards 2003, 30, 281-295. [CrossRef]

3. Ba, Q.; Chen, Y.; Deng, S.; Wu, Q.; Yang, J.; Zhang, J. An improved information value model based on gray clustering for landslide susceptibility mapping. ISPRS Int. J. Geo-Inf. 2017, 6, 18. [CrossRef]

4. Lee, S.; Lee, M.-J.; Jung, H.-S. Data mining approaches for landslide susceptibility mapping in Umyeonsan, Seoul, South Korea. Appl. Sci. 2017, 7, 683. [CrossRef]

5. Capitani, M.; Ribolini, A.; Bini, M. Susceptibility to Translational Slide-Type Landslides: Applicability of the Main Scarp Upper Edge as a Dependent Variable Representation by Reduced Chi-Square Analysis. ISPRS Int. J. Geo-Inf. 2018, 7, 336. [CrossRef]

6. Bathrellos, G.D.; Skilodimou, H.D.; Chousianitis, K.; Youssef, A.M.; Pradhan, B. Suitability estimation for urban development using multi-hazard assessment map. Sci. Total Environ. 2017, 575, 119-134. [CrossRef] [PubMed]

7. Fell, R.; Corominas, J.; Bonnard, C.; Cascini, L.; Leroi, E.; Savage, W.Z. Guidelines for landslide susceptibility, hazard and risk zoning for land use planning. Eng. Geol. 2008, 102, 85-98. [CrossRef]

8. Skilodimou, H.; Bathrellos, G.; Koskeridou, E.; Soukis, K.; Rozos, D. Physical and anthropogenic factors related to landslide activity in the Northern Peloponnese, Greece. Land 2018, 7, 85. [CrossRef]

9. Clerici, A.; Perego, S.; Tellini, C.; Vescovi, P. A GIS-based automated procedure for landslide susceptibility mapping by the conditional analysis method: The Baganza valley case study (Italian Northern Apennines). Environ. Geol. 2006, 50, 941-961. [CrossRef]

10. Shou, K.-J.; Wang, C.-F. Analysis of the Chiufengershan landslide triggered by the 1999 Chi-Chi earthquake in Taiwan. Eng. Geol. 2003, 68, 237-250. [CrossRef]

11. Dou, J.; Yamagishi, H.; Pourghasemi, H.R.; Yunus, A.P.; Song, X.; Xu, Y.; Zhu, Z. An integrated artificial neural network model for the landslide susceptibility assessment of Osado Island, Japan. Nat. Hazards 2015, 78, 1749-1776. [CrossRef]

12. Scolobig, A.; Pelling, M. The co-production of risk from a natural hazards perspective: Science and policy interaction for landslide risk management in Italy. Nat. Hazards 2016, 81, 7-25. [CrossRef]

13. Pradhan, B.; Chaudhari, A.; Adinarayana, J.; Buchroithner, M.F. Soil erosion assessment and its correlation with landslide events using remote sensing data and GIS: A case study at Penang Island, Malaysia. Environ. Monit. Assess. 2012, 184, 715-727. [CrossRef] [PubMed]

14. Akgun, A.; Dag, S.; Bulut, F. Landslide susceptibility mapping for a landslide-prone area (Findikli, NE of Turkey) by likelihood-frequency ratio and weighted linear combination models. Environ. Geol. 2008, 54, 1127-1143. [CrossRef]

15. Youssef, A.M.; Pradhan, B.; Gaber, A.F.D.; Buchroithner, M.F. Geomorphological hazard analysis along the Egyptian Red Sea coast between Safaga and Quseir. Nat. Hazards Earth Syst. Sci. 2009, 9. [CrossRef]

16. Pourghasemi, H.R.; Pradhan, B.; Gokceoglu, C.; Moezzi, K.D. Landslide Susceptibility Mapping Using a Spatial Multi Criteria Evaluation Model at Haraz Watershed, Iran; Springer: Berlin, Heidelberg, 2012; pp. 23-49, ISBN 9783642254956.

17. Hasekioğulları, G.D.; Ercanoglu, M. A new approach to use AHP in landslide susceptibility mapping: A case study at Yenice (Karabuk, NW Turkey). Nat. Hazards 2012, 63, 1157-1179. [CrossRef]

18. Kayastha, P.; Dhital, M.R.; De Smedt, F. Application of the analytical hierarchy process (AHP) for landslide susceptibility mapping: A case study from the Tinau watershed, west Nepal. Comput. Geosci. 2013, 52, 398-408. [CrossRef] 
19. Ayalew, L.; Yamagishi, H.; Ugawa, N. Landslide susceptibility mapping using GIS-based weighted linear combination, the case in Tsugawa area of Agano River. Niigata Prefect. Jpn. 2004, 1, 73-81.

20. Yoshimatsu, H.; Abe, S. A review of landslide hazards in Japan and assessment of their susceptibility using an analytical hierarchic process (AHP) method. Landslides 2006, 3, 149-158. [CrossRef]

21. Akgun, A. A comparison of landslide susceptibility maps produced by logistic regression, multi-criteria decision, and likelihood ratio methods: A case study at İzmir, Turkey. Landslides 2012, 9, 93-106. [CrossRef]

22. Jaafari, A.; Najafi, A.; Pourghasemi, H.R.; Rezaeian, J.; Sattarian, A. GIS-based frequency ratio and index of entropy models for landslide susceptibility assessment in the Caspian forest, northern Iran. Int. J. Environ. Sci. Technol. 2014, 11, 909-926. [CrossRef]

23. Youssef, A.M.; Pradhan, B.; Pourghasemi, H.R.; Abdullahi, S. Landslide susceptibility assessment at Wadi Jawrah Basin, Jizan region, Saudi Arabia using two bivariate models in GIS. Geosci. J. 2015, 19, 449-469. [CrossRef]

24. Saha, A.K.; Gupta, R.P.; Sarkar, I.; Arora, M.K.; Csaplovics, E. An approach for GIS-based statistical landslide susceptibility zonation with a case study in the Himalayas. Landslides 2005, 2, 61-69. [CrossRef]

25. Yilmaz, I.; Yildirim, M. Structural and geomorphological aspects of the Kat landslides (Tokat-Turkey) and susceptibility mapping by means of GIS. Environ. Geol. 2006. [CrossRef]

26. Yalcin, A.; Reis, S.; Aydinoglu, A.C.; Yomralioglu, T. A GIS-based comparative study of frequency ratio, analytical hierarchy process, bivariate statistics and logistics regression methods for landslide susceptibility mapping in Trabzon, NE Turkey. Catena 2011, 85, 274-287. [CrossRef]

27. Nandi, A.; Shakoor, A. A GIS-based landslide susceptibility evaluation using bivariate and multivariate statistical analyses. Eng. Geol. 2010, 110, 11-20. [CrossRef]

28. Bui, D.T.; Lofman, O.; Revhaug, I.; Dick, O.B. Landslide susceptibility analysis in the Hoa Binh province of Vietnam using statistical index and logistic regression. Nat. Hazards 2011, 59, 3. [CrossRef]

29. Regmi, A.D.; Yoshida, K.; Pourghasemi, H.R.; DhitaL, M.R.; Pradhan, B. Landslide susceptibility mapping along Bhalubang-Shiwapur area of mid-Western Nepal using frequency ratio and conditional probability models. J. Mt. Sci. 2014, 11, 1266-1285. [CrossRef]

30. Kayastha, P.; Dhital, M.R.; De Smedt, F. Landslide susceptibility mapping using the weight of evidence method in the Tinau watershed, Nepal. Nat. Hazards 2012, 63, 479-498. [CrossRef]

31. Pourghasemi, H.R.; Pradhan, B.; Gokceoglu, C.; Moezzi, K.D. A comparative assessment of prediction capabilities of Dempster-Shafer and Weights-of-evidence models in landslide susceptibility mapping using GIS. Geomat. Nat. Hazards Risk 2013, 4, 93-118. [CrossRef]

32. Regmi, A.D.; Devkota, K.C.; Yoshida, K.; Pradhan, B.; Pourghasemi, H.R.; Kumamoto, T.; Akgun, A. Application of frequency ratio, statistical index, and weights-of-evidence models and their comparison in landslide susceptibility mapping in Central Nepal Himalaya. Arab. J. Geosci. 2014, 7, 725-742. [CrossRef]

33. Muthu, K.; Petrou, M.; Tarantino, C.; Blonda, P. Landslide possibility mapping using fuzzy approaches. IEEE Trans. Geosci. Remote Sens. 2008, 46, 1253-1265. [CrossRef]

34. Pradhan, B.; Lee, S. Landslide risk analysis using artificial neural network model focussing on different training sites. Int. J. Phys. Sci. 2009, 4, 1-15.

35. Pourghasemi, H.R.; Mohammady, M.; Pradhan, B. Landslide susceptibility mapping using index of entropy and conditional probability models in GIS: Safarood Basin, Iran. Catena 2012, 97, 71-84. [CrossRef]

36. Lee, S.; Ryu, J.H.; Won, J.S.; Park, H.J. Determination and application of the weights for landslide susceptibility mapping using an artificial neural network. Eng. Geol. 2004, 71, 289-302. [CrossRef]

37. Pradhan, B.; Sezer, E.A.; Gokceoglu, C.; Buchroithner, M.F. Landslide susceptibility mapping by neuro-fuzzy approach in a landslide-prone area (Cameron Highlands, Malaysia). IEEE Trans. Geosci. Remote Sens. 2010, 48, 4164-4177. [CrossRef]

38. Yilmaz, I. Landslide susceptibility mapping using frequency ratio, logistic regression, artificial neural networks and their comparison: A case study from Kat landslides (Tokat-Turkey). Comput. Geosci. 2009, 35, 1125-1138. [CrossRef]

39. Yilmaz, I. The effect of the sampling strategies on the landslide susceptibility mapping by conditional probability and artificial neural networks. Environ. Earth Sci. 2010, 60, 505-519. [CrossRef]

40. Zare, M.; Pourghasemi, H.R.; Vafakhah, M.; Pradhan, B. Landslide susceptibility mapping at Vaz Watershed (Iran) using an artificial neural network model: A comparison between multilayer perceptron (MLP) and radial basic function (RBF) algorithms. Arab. J. Geosci. 2013, 6, 2873-2888. [CrossRef] 
41. Sezer, E.A.; Pradhan, B.; Gokceoglu, C. Manifestation of an adaptive neuro-fuzzy model on landslide susceptibility mapping: Klang valley, Malaysia. Expert Syst. Appl. 2011, 38, 8208-8219. [CrossRef]

42. Oh, H.J.; Pradhan, B. Application of a neuro-fuzzy model to landslide-susceptibility mapping for shallow landslides in a tropical hilly area. Comput. Geosci. 2011, 37, 1264-1276. [CrossRef]

43. Bui, D.T.; Pradhan, B.; Lofman, O.; Revhaug, I.; Dick, O.B. Landslide susceptibility mapping at Hoa Binh province (Vietnam) using an adaptive neuro-fuzzy inference system and GIS. Comput. Geosci. 2012, 45, 199-211.

44. Marjanović, M.; Kovačević, M.; Bajat, B.; Voženílek, V. Landslide susceptibility assessment using SVM machine learning algorithm. Eng. Geol. 2011, 123, 225-234. [CrossRef]

45. Bui, D.T.; Pradhan, B.; Lofman, O.; Revhaug, I.; Dick, O.B. Spatial prediction of landslide hazards in Hoa Binh province (Vietnam): A comparative assessment of the efficacy of evidential belief functions and fuzzy logic models. Catena 2012, 96, 28-40.

46. Althuwaynee, O.F.; Pradhan, B.; Lee, S. Application of an evidential belief function model in landslide susceptibility mapping. Comput. Geosci. 2012, 44, 120-135. [CrossRef]

47. Akgun, A.; Türk, N. Landslide susceptibility mapping for Ayvalik (Western Turkey) and its vicinity by multicriteria decision analysis. Environ. Earth Sci. 2010, 61, 595-611. [CrossRef]

48. Gokceoglu, C.; Nefeslioglu, H.A.; Sezer, E.; Bozkir, A.S.; Duman, T.Y. Assessment of landslide susceptibility by decision trees in the metropolitan area of Istanbul, Turkey. Math. Probl. Eng. 2010, 2010, 901095.

49. Tsangaratos, P.; Ilia, I. Landslide susceptibility mapping using a modified decision tree classifier in the Xanthi Perfection, Greece. Landslides 2016, 13, 305-320. [CrossRef]

50. Miner, A.; Vamplew, P.; Windle, D.J.; Flentje, P.; Warner, P. A comparative study of Various Data Mining techniques as applied to the modeling of Landslide susceptibility on the Bellarine Peninsula, Victoria, Australia. In Proceedings of the 11th IAEG Congress of the International Association of Engineering Geology and the Environment, Auckland, New Zealand, 5-10 September 2010.

51. Choi, J.; Oh, H.J.; Lee, H.; Lee, C.; Lee, S. Combining landslide susceptibility maps obtained from frequency ratio, logistic regression, and artificial neural network models using ASTER images and GIS. Eng. Geol. 2012, 124, 12-23. [CrossRef]

52. Shahabi, H.; Khezri, S.; Ahmad, B.B.; Hashim, M. Landslide susceptibility mapping at central Zab basin, Iran: A comparison between analytical hierarchy process, frequency ratio and logistic regression models. Catena 2014, 115, 55-70. [CrossRef]

53. Youssef, A.M.; Pourghasemi, H.R.; Pourtaghi, Z.S.; Al-Katheeri, M.M. Landslide susceptibility mapping using random forest, boosted regression tree, classification and regression tree, and general linear models and comparison of their performance at Wadi Tayyah Basin, Asir Region, Saudi Arabia. Landslides 2016, 13, 839-856. [CrossRef]

54. Pradhan, B. A comparative study on the predictive ability of the decision tree, support vector machine and neuro-fuzzy models in landslide susceptibility mapping using GIS. Comput. Geosci. 2013, 51, 350-365. [CrossRef]

55. Geneletti, D.; Beinat, E.; Chung, C.F.; Fabbri, A.G.; Scholten, H.J. Accounting for uncertainty factors in biodiversity impact assessment: Lessons from a case study. Environ. Impact Assess. Rev. 2003, 23, 471-487. [CrossRef]

56. Drobnjak, S.; Sekulović, D.; Amović, M.; Gigović, L.; Regodić, M. Central geospatial database analysis of the quality of road infrastructure data I Analiza kakovosti podatkov cestne infrastrukture kot dela centralne geoprostorske podatkovne zbirke. Geod. Vestn. 2016, 60, 269-285. [CrossRef]

57. Rezaei, J. Best-worst multi-criteria decision-making method. Omega 2015, 53, 49-57. [CrossRef]

58. Rezaei, J.; Wang, J.; Tavasszy, L. Linking supplier development to supplier segmentation using Best Worst Method. Expert Syst. Appl. 2015, 42, 9152-9164. [CrossRef]

59. Badi, I.; Ballem, M. Supplier Selection using rough BWM-MAIRCA model: A case study in pharmaceutical supplying in Libya. Decis. Mak. Appl. Manag. Eng. 2018, 1, 15-32. [CrossRef]

60. Mukhametzyanov, I.; Pamucar, D. A sensitivity analysis in MCDM problems: A statistical approach. Decis. Mak. Appl. Manag. Eng. 2018, 1, 51-80. [CrossRef]

61. Pamučar, D.; Gigović, L.; Ćirović, G.; Regodić, M. Transport spatial model for the definition of green routes for city logistics centers. Environ. Impact Assess. Rev. 2016, 56, 72-87. [CrossRef] 
62. Ren, J.; Liang, H.; Chan, F.T. Urban sewage sludge, sustainability, and transition for Eco-City: Multi-criteria sustainability assessment of technologies based on best-worst method. Technol. Forecast. Soc. Change 2017, 116, 29-39. [CrossRef]

63. Liu, F.; Aiwu, G.; Lukovac, V.; Vukic, M. A multicriteria model for the selection of the transport service provider: A single valued neutrosophic DEMATEL multicriteria model. Decis. Mak. Appl. Manag. Eng. 2018, 1, 121-130. [CrossRef]

64. Ayalew, L.; Yamagishi, H.; Marui, H.; Kanno, T. Landslides in Sado Island of Japan: Part II. GIS-based susceptibility mapping with comparisons of results from two methods and verifications. Eng. Geol. 2005, 81, 432-445. [CrossRef]

65. Moore, I.D.; Grayson, R.B.; Ladson, A.R. Digital terrain modelling: A review of hydrological, geomorphological, and biological application. Hydrol. Process. 1991, 5, 3-30. [CrossRef]

66. Moore, I.D.; Gessler, P.E.; Nielsen, G.A.; Peterson, G.A. Soil attribute prediction using terrain analysis. Soil Sci. Soc. Am. J. 1993, 57, 443-452. [CrossRef]

67. Sassa, K.; Fukuoka, H.; Wang, F.; Wang, G. Landslides: Risk Analysis and Sustainable Disaster Management; Springer Science \& Business Media: Berlin, Germany, 2006.

68. He, S.; Pan, P.; Dai, L.; Wang, H.; Liu, J. Application of kernel-based Fisher discriminant analysis to map landslide susceptibility in the Qinggan River delta, Three Gorges, China. Geomorphology 2012, 171, 30-41. [CrossRef]

69. Zadeh, L.A. Fuzzy Sets.pdf. Inf. Control 1965, 8, 338-353. [CrossRef]

70. Gigović, L.; Pamucar, D.; Božanić, D.; Ljubojević, S. Application of the GIS-DANP-MABAC multi-criteria model for selecting the location of wind farms: A case study of Vojvodina, Serbia. Renew. Energy 2017, 103, 501-521.

71. Gigović, L.; Pamucar, D.; Bajić, Z.; Drobnjak, S. Application of GIS-Interval Rough AHP Methodology for Flood Hazard Mapping in Urban Areas. Water 2017, 9, 360. [CrossRef]

72. Gigović, L.; Pamucar, D.; Bajić, Z.; Milićević, M. The combination of expert judgment and GIS-MAIRCA analysis for the selection of sites for ammunition depots. Sustainability 2016, 8, 372. [CrossRef]

73. Yager, R.R. On ordered weighted averaging aggregation operators in multicriteria decisionmaking. IEEE Trans. Syst. Man. Cybern. 1988, 18, 183-190. [CrossRef]

74. Malczewski, J. GIS-based multicriteria decision analysis: A survey of the literature. Int. J. Geogr. Inf. Sci. 2006, 20, 703-726. [CrossRef]

75. Yager, R.R. Generalized OWA aggregation operators. Fuzzy Optim. Decis. Mak. 2004, 3, 1-12. [CrossRef]

76. Jiang, H.; Eastman, J.R. Application of fuzzy measures in multi-criteria evaluation in GIS. Int. J. Geogr. Inf. Sci. 2000, 14, 173-184. [CrossRef]

77. Boroushaki, S.; Malczewski, J. Using the fuzzy majority approach for GIS-based multicriteria group decision-making. Comput. Geosci. 2010, 36, 302-312. [CrossRef]

78. Pourghasemi, H.R.; Pradhan, B.; Gokceoglu, C. Application of fuzzy logic and analytical hierarchy process (AHP) to landslide susceptibility mapping at Haraz watershed, Iran. Nat. Hazards 2012, 63, 965-996. [CrossRef]

79. Hong, H.; Naghibi, S.A.; Dashtpagerdi, M.M.; Pourghasemi, H.R.; Chen, W. A comparative assessment between linear and quadratic discriminant analyses (LDA-QDA) with frequency ratio and weights-of-evidence models for forest fire susceptibility mapping in China. Arab. J. Geosci. 2017, 10, 167. [CrossRef]

80. Pham, B.T.; Tien Bui, D.; Pourghasemi, H.R.; Indra, P.; Dholakia, M.B. Landslide susceptibility assesssment in the Uttarakhand area (India) using GIS: A comparison study of prediction capability of naïve bayes, multilayer perceptron neural networks, and functional trees methods. Theor. Appl. Climatol. 2017, 128, 255-273. [CrossRef]

81. Pourghasemi, H.R.; Moradi, H.R.; Fatemi Aghda, S.M. Landslide susceptibility mapping by binary logistic regression, analytical hierarchy process, and statistical index models and assessment of their performances. Nat. Hazards 2013, 69, 749-779. [CrossRef]

82. Hong, H.; Naghibi, S.A.; Pourghasemi, H.R.; Pradhan, B. GIS-based landslide spatial modeling in Ganzhou City, China. Arab. J. Geosci. 2016, 9, 1-26. [CrossRef] 
83. Dou, J.; Oguchi, T.; Hayakawa, Y.S.; Uchiyama, S.; Saito, H.; Paudel, U. GIS-based landslide susceptibility mapping using a certainty factor model and its validation in the Chuetsu Area, Central Japan. In Landslide Science for a Safer Geoenvironment, Cham; Springer: Berlin, Germany, 2014; pp. 419-424.

84. Nunić, Z. Evaluation and selection of Manufacturer PVC carpentry using FUCOM-MABAC model. Oper. Res. Eng. Sci. Theor. Appl. 2018, 1, 13-28. [CrossRef]

85. Pamučar, D.; Lukovac, V.; Božanić, D.; Komazec, N. Multi-criteria FUCOM-MAIRCA model for the evaluation of level crossings: Case study in the Republic of Serbia. Oper. Res. Eng. Sci. Theor. Appl. 2018, 1, 108-129.

86. Petrovic, I.; Kankaras, M. DEMATEL-AHP multi-criteria decision making model for the selection and evaluation of criteria for selecting an aircraft for the protection of air traffic. Decis. Mak. Appl. Manag. Eng. 2018, 1, 93-110. [CrossRef]

87. Stanujkić, D.; Karabašević, D. An extension of the WASPAS method for decision-making problems with intuitionistic fuzzy numbers: A case of website evaluation. Oper. Res. Eng. Sci. Theor. Appl. 2018, 1, $29-39$.

88. Pamučar, D.; Božanić, D.; Lukovac, V.; Komazec, N. Normalized weighted geometric bonferroni mean operator of interval rough numbers-Application in interval rough DEMATEL-COPRAS. FU. Mech. Eng. 2018, 16, 171-191.

(C) 2019 by the authors. Licensee MDPI, Basel, Switzerland. This article is an open access article distributed under the terms and conditions of the Creative Commons Attribution (CC BY) license (http://creativecommons.org/licenses/by/4.0/). 